Portland State University

PDXScholar

Winter 3-11-2016

\title{
Learning Through Nature: A Study of a Next Generation Science Standards Based Teacher Workshop that Blends Outdoor Learning Experiences with Formal Science
}

Ashley Fanning

Portland State University

Follow this and additional works at: https://pdxscholar.library.pdx.edu/open_access_etds

Part of the Educational Methods Commons, Elementary Education and Teaching Commons, and the Science and Mathematics Education Commons

Let us know how access to this document benefits you.

\section{Recommended Citation}

Fanning, Ashley, "Learning Through Nature: A Study of a Next Generation Science Standards Based Teacher Workshop that Blends Outdoor Learning Experiences with Formal Science" (2016). Dissertations and Theses. Paper 2731.

https://doi.org/10.15760/etd.2727

This Thesis is brought to you for free and open access. It has been accepted for inclusion in Dissertations and Theses by an authorized administrator of PDXScholar. Please contact us if we can make this document more accessible: pdxscholar@pdx.edu. 
Learning Through Nature: A Study of a Next Generation Science Standards Based Teacher Workshop that Blends Outdoor Learning Experiences with Formal Science

by

Ashley Fanning

A thesis submitted in partial fulfillment of the requirements for the degree of

Master of Science in Teaching

in

General Science

Thesis Committee:

William Becker, Chair

Christina Trecha

Stephanie Wagner

Portland State University

2016 


\begin{abstract}
Many teachers lack the confidence and knowledge to transition their classroom science lessons to an outdoor setting. Very few teacher professional development (PD) programs focus on improving teachers' self-efficacy and pedagogical content knowledge (PCK) that is needed to enhance their science curriculum with outdoor lessons. This study examined an exception: The Connect2Science workshops, which provided elementary teachers the opportunity to experience nature-based science lessons. My research question for this study is: In what ways does a professional development workshop focused around the Next Generation Science Standards influence teachers': a) self-efficacy in teaching science outdoors and b) science pedagogical content knowledge? Data was collected using a retrospective pre and post survey, a reflection piece on participants' pedagogical content knowledge and semi-structured interviews. The results showed that participants' self-efficacy was positively affected by the Connect2Science workshops. As for pedagogical content knowledge, the results give a small insight into how participants viewed and thought about student misconceptions and how the instructional strategies presented in the workshops equipped them to better address science content in an outdoor setting.
\end{abstract}




\section{Table of Contents}

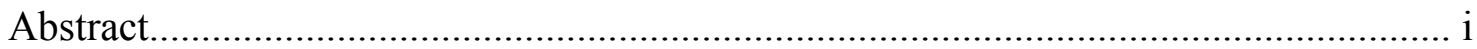

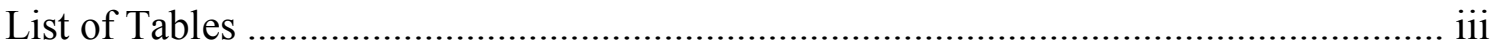

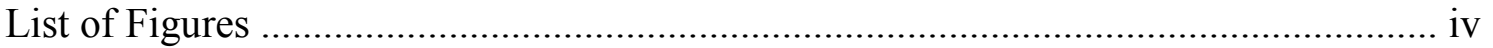

Chapter 1

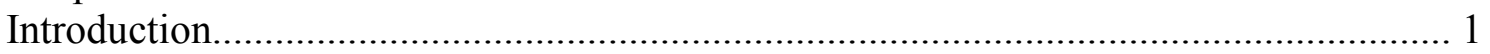

Chapter 2

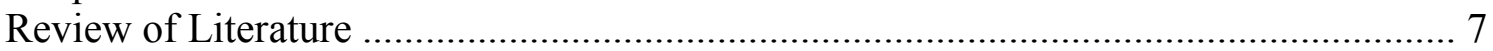

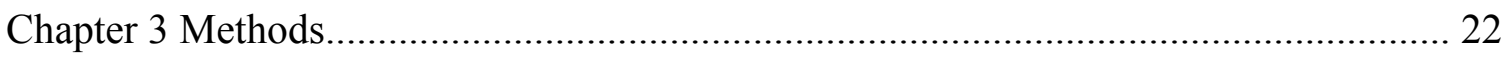

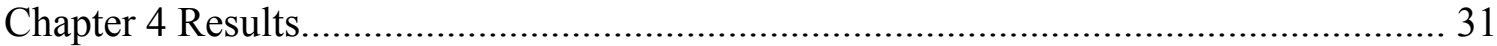

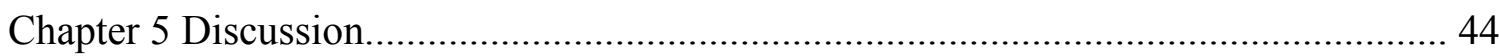

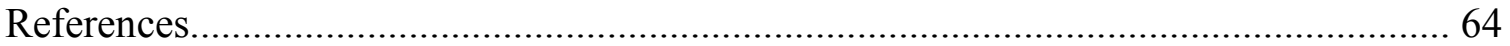

Appendices

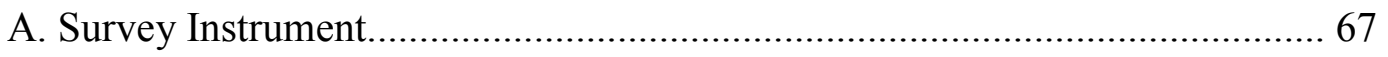

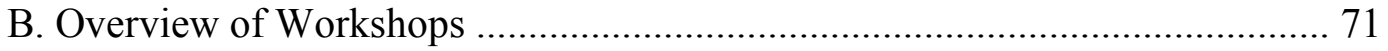

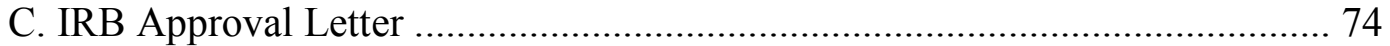


List of Tables

Table 1. Workshop Treatment Outline .................................. 23

Table 2. Overview of Participants ...................................... 25

Table 3. Participant's Pre and Post Self-Efficacy Sums ..................... 31

Table 4. Pedagogical Content Knowledge Reflection Summary ................ 34

Table 5. Common Student Misconceptions ................................ 35

Table 6. Supporting Interview Data for Self-Efficacy Constructs .............. 36 


\section{List of Figures}

Figure 1. Statistical Analysis of Self-Efficacy Constructs ..................... 33

Figure 2. Coded Interview Answers ..................................... 37 


\section{Chapter 1: Introduction}

Educators have dealt with a constant struggle to foster an appreciation of science for the majority of students for decades. Braund and Reiss (2006) comment that many teachers around the world are concerned that current science curricula are boring, irrelevant, and outdated; failing to instill scientific understanding, reasoning, and literacy required for students to be engaged citizens in today's world. There has been a growing consensus that learning experiences that take place outside of the classroom are often more exciting, uplifting and relevant (Braund \& Reiss, 2006). Some researchers suggest that learning processes that take place in nature should be encouraged and incorporated into the curriculum (Feille, 2013). Blending informal instruction with traditional curriculum can help to foster deeper connections to learning science for students by providing new uplifting experiences.

Informal learning experiences have long been recognized as a powerful tool to enhance formal classroom learning (Braund \& Reiss, 2006; Jung \& Tonso, 2006; Pecore, Kirchgessner, \& Carruth, 2013). The National Science Foundation (2012) defines informal education as learning that takes place outside of the classroom. The belief that informal settings play a valuable role in science education is present throughout many reform documents. The National Science Education Standards (NSES) states, "The classroom is a limited environment. The school science program must extend beyond the walls of the school to the resources of the community" (National Research Council [NRC], 1996, p.45). The most accessible way of incorporating informal learning into formal settings is to utilize the outdoor spaces around schools since there is some kind of outdoor space at every school. Aligning classroom curriculum with outdoor spaces can 
provide rich and meaningful learning experiences, which leads to higher student achievement (Lieberman \& Hoody, 1998). Also, informal learning settings have the potential to cultivate the wonder of discovery, which may help make science more exciting and relevant for students (Jung \& Tonso, 2006). Outdoor education provides students with new perspectives and can strengthen their understanding of complex topics (Holden et. al., 2011). However, many elementary school teachers tend to be uncomfortable taking students outside for lessons. Elementary teachers tend to encounter challenges that prevent them from taking advantage of the natural settings surrounding their schools as a substitute for classroom instruction (Holden et. al., 2011). The sources of these challenges can be external, such as time, or internal, such as a lack of self-efficacy and pedagogical content knowledge (PCK) of outdoor education (Bloom et al., 2010).

The task of creating learning environments conducive to the development of students' learning capabilities rests heavily on the talents and confidence levels of teachers (Bandura, 1997). Bandura's social cognitive theory has played a large role in shaping selfefficacy research. For this study, teacher self-efficacy is the level of confidence a teacher has and the extent to which he or she believes they can affect student learning in teaching science in an outdoor setting. Teacher self-efficacy has been shown to influence student achievement (Ashton \& Webb, 1986). Many teachers feel comfortable teaching in their classroom and the thought of teaching in any other setting makes them quickly lose all confidence in their abilities, closing the door on opportunities to enhance their students learning. Administrators and teachers tend to have reservations about liability, student safety, and the lack of academic benefits linked to many outdoor activities when compared with the efforts spent (Holden et. al., 2011). Teachers with high self-efficacy are more 
likely to try new and innovative instructional methods that aim to enhance student learning (Tschannen-Moran, Hoy \& Hoy, 1998).

Teachers may lack self-efficacy in a specific area, such as ecology, or generally, science. A teacher's past science experiences and the number of science courses taken during college is a strong influencing factor on their self-efficacy for teaching science (Holden et. al., 2011). Educators who don't feel comfortable teaching a certain subject will avoid incorporating demonstrations and inquiry-based activities into their teaching, often afraid that their limited knowledge will be revealed (Sandholtz \& Ringstaff, 2014). While having a strong science background can lead to improved self-efficacy it is also important to know how to express the content knowledge in a way that is understandable to students, which has become known as a teacher's pedagogical content knowledge (PCK).

Lee Shulman introduced the idea of pedagogical content knowledge in 1986 when he proposed that teaching requires more than subject matter knowledge. He stated "the ultimate test of understanding rests on the ability to transform one's knowledge into teaching" (Shulman, 1986, p. 14). According to Shulman, effective teachers combine content and pedagogical knowledge, creating a new kind of knowledge that they use to teach specific topics. Over time a teacher's pedagogical content knowledge (PCK) has come to mean the knowledge that a teacher has of strategies and representations for teaching science content and the teacher's knowledge of student's understanding, including conceptions and misconceptions (Van Driel, Verloop, \& de Vos 1998; Appleton, 2008; Cochran, 1991). Knowledge of student misconceptions is an important part of a teacher's PCK (Cochran, 1991; Van Driel, Verloop, \& de Vos 1998). Teachers need knowledge of the strategies that are going to be the most effective in reconstructing the understanding of 
students, since students are unlikely to come to them as blank slates (Shulman, 1986).

Designing effective professional development (PD) programs for teachers as a way to improve student achievement has become an important area of focus in recent years (Lakshmanan et al., 2011; Sandholtz \& Ringstaff, 2014). The link between teacher professional workshops and student achievement has been studied extensively, but what makes an effective PD program is still under examination (Lakshmanan et al., 2011; Sandholtz \& Ringstaff, 2013). Studies have shown that professional development (PD) programs can improve teacher self-efficacy and PCK. Lakshmanan et al. (2011) found that participants in a standards-based PD program that provided hands-on learning experiences showed significant growth in self-efficacy over the course of the program. Pecore, Kirchgessner and Carruth (2013) found that a zoo-based PD program provided authentic learning experiences that improved science content knowledge and pedagogy. According to the NSES (NRC, 1996), professional development of science teachers should involve teachers in scientific investigations that allow them to explore not only the content, but the process of science as well. Understanding the process that scientists go through helps to give educators a feel for how real science is done. Putting themselves in the shoes of a scientist allows them to gain experiences to see that science doesn't need to be boring and rigid. It has been shown that educators who want to improve their science teaching value PD programs that provide authentic, hands-on experiences as well as exposure to real scientists (Pecore, Kirchgessner, \& Carruth, 2013). However, not many PD programs have used informal learning experiences to help educate and prepare teachers for transitioning science lessons to an outdoor setting (Jung \& Tonso, 2006). The Connect2Science professional program at Tryon Creek State Park does exactly that. 
Connect2Science was a series of full-day teacher workshops that aim at helping teachers take their students outside for science lessons. Tryon Creek State Park provides a unique setting for these workshops because it is a natural area located within a large urban area. The park is not untouched by the urban surroundings. Tryon Creek appears to be a beautiful naturally forested area. However, the land was once contracted to be a section of new housing development and sewer systems were installed throughout the park. While these disturbances to the natural ecosystem are unfortunate, it helps to create an environment that is similar to a schoolyard. Many teachers don't have access to large forested area, but they do have access to the outdoor area surrounding their schools. Being able to relate Tryon to their schoolyards helps to create the notion that a multitude of different learning environments lie right outside their classrooms.

The objectives of the Connect2Science workshops are to: a) present participating teachers with outdoor learning activities that complement their existing science knowledge; b) model the use of outdoor environments for instruction; c) improve the PCK skills of participants; and d) provide direction in aligning outdoor instruction with formal science instruction identified in the Next Generation Science Standards. Professional developers have identified active instructional development strategies as more effective in increasing teacher self-efficacy (Holden et al., 2011). Participants of the workshops experienced hands-on outdoor learning activities. This allowed them to go through the steps of each activity as if they were their students.

The Connect2Science program is a unique teacher development experience that has a progressive objective of motivating teachers to incorporate outdoor learning into their science curriculum. Very little research has been done on the effects of nature based 
PD programs on teachers' self-efficacy and pedagogical content knowledge (PCK) (Jung \& Tonso, 2006). My research question is: In what ways does the Tryon Creek Connect2Science professional development workshop influence teachers': a) self-efficacy in teaching science outdoors and b) science pedagogical content knowledge? The Connect2Science workshop is the independent variable. Self-efficacy and PCK of the teachers who attend the Connect2Science workshops are the dependent variables. I used surveys and interviews to assess and measure any changes in the participants' self-efficacy and PCK over the course of the workshops. I predicted that involvement in the Connect2Science workshops would increase participant's self-efficacy to incorporate outdoor science lessons into their curriculum, as well as positively influence participants' science PCK, since the workshops supplied participants with multiple activities that allowed them to gain new ideas and insights to enhance their science instruction. 


\section{Chapter 2: Review of Literature}

In this chapter I start by outlining studies that have looked at programs that have incorporated outdoor learning into science curriculum. Then I have included a few papers that discuss the importance of a teacher's self-efficacy and PCK in influencing student learning, followed by some studies that have looked at how professional development programs influence teacher self-efficacy and PCK. I also highlight a few papers and studies that take a look at the importance of outdoor learning experiences in teaching science and a couple of PD programs that have been developed to help teacher's gain the confidence and skills to incorporate the outdoors into their science curricula.

\section{Enhancing Formal Education with Outdoor Experiences}

Braund and Reiss (2006) present a model of science education that examines how out-of-school learning experiences can complement formal science curriculum. The authors view out-of school learning experiences as ways to improve the learning of science in five ways: improve development and integration of concepts, provide authentic practical work, allow access to rare material and to "big" science, stimulate further learning, and promote collaborative work and responsibility for learning. The researchers state that out-of-school science learning can occur in many places, such as field trips to science museums, botanical gardens, nature centers, or even short outings in the residential community of the school. Braund and Reiss view these various outings as a way to provide practical science that adds authenticity to learning since students often perceive these informal experiences as having relevance to their lives. In conclusion the authors argue that formal science curriculum is too restrictive, which often leads to a 
science education that is less authentic and un-motivating.

Lieberman and Hoody (1998) examined a program called Environment as the Integrating Context for learning (EIC), which focuses on using the surrounding areas and community around schools as a framework for school curriculum. The researchers state that the term "environment" can mean a variety of things for each school, such as a river, a forest, a city park, or a garden. The EIC approach to teaching allows students to construct their own learning and attempt to provide students with the opportunity to connect what they are learning to their surroundings. Students that take part in EIC curriculum are not just learning science, they are doing science. The study investigated EIC programs that were being implemented at 40 schools, which included elementary, middle and high schools that were located across 13 states. Each of the schools that were part of the study were visited by researchers for a full day. During these visits, teachers, principals, school district staff, students, and community members were interviewed. After site visits, researchers sent each school three separate surveys for teachers and administers to aid in the analysis of data collected through interviews: a learning survey, teaching survey and domain survey. The researchers found that EIC students throughout the 40 schools demonstrated a deeper understanding of complex scientific concepts than students who participated in more traditional education. Data from the surveys also indicated that teachers and administers found EIC learning to be an effective process in helping students develop scientific knowledge and skills.

According to the model proposed by Braund and Reiss (2006), and the extensive study of 40 schools by Lieberman and Hoody (1998), blending informal education with formal curriculum can enhance students' learning. These two studies support the idea that 
integrating outdoor education with science curriculum provides teachers with new opportunities to create experiences that make learning more authentic and relevant.

Importance of Teacher Self-Efficacy

Tschannen-Moran, Hoy and Hoy (1998) discuss how two separate theoretical bases have been defined over the years that have guided many studies on self-efficacy. The intertwining of these two dominant theories has led to a lack of clarity about the nature of teacher self-efficacy. In order to help bring some clarity to this important teaching construct, the authors review multiple studies on the topic in order to help unify the two competing theories. The authors examine multiple instruments that have been developed over the years to assess self-efficacy in order to discover possible patterns that could provide a better understanding of teacher self-efficacy that could lead to an improvement in measuring the concept. The model that the authors developed suggests that in order to measure teacher efficacy validly the measurement instrument should encompass both the assessment of personal competence as well as an analysis of the resources and constraints that exist in particular teaching contexts. The assessment of factors that facilitate and/or impede teaching tend to produce more powerful instruments. The authors recommend that an assessment should be weighted to reflect the importance of different aspects of the job. However, Tschannen-Moran, Hoy and Hoy add that one of the most difficult issues with measuring teacher self-efficacy is determining the level of specificity. In the end, the authors conclude that more interpretive case studies and qualitative investigations need to be done to help refine what we understand about developing teacher self-efficacy.

Bandura (1997) established one of the core theories that influenced many research 
projects on self-efficacy. The author reviewed multiple research studies and came to the conclusion that personal self-efficacy is not a measure of skills but rather it is a belief about what one is capable of doing under any circumstances with the skills one possesses. Teachers have the task of creating environments where students can learn and develop their cognitive capabilities. A teacher's ability to create effective learning environments rests heavily on their self-efficacy. Teachers' beliefs in their ability to instruct students can strongly determine their classroom activities, and impact how students evaluate their own capabilities. Students have been shown to learn more from teachers with a high sense of self-efficacy than from those with self-doubts. A teacher's sense of efficacy can be especially influential on young children, who are likely to have uncertain beliefs about their capabilities. Teachers who lack self-efficacy have been shown to have a weaker commitment to teaching and often will spend less time teaching subjects that they are not comfortable with.

Ashton and Webb (1986) conducted a classroom observation study of high school basic skills classes to examine the relationship between teachers' self-efficacy and students' achievement. Forty-eight basic skills teachers in mathematics and communications participated in the study, and were observed two to three times a day over a two-month period. In the spring before the classroom observations, students were given subtests of the Metropolitan Achievement Test (MAT) in mathematics, language, and reading to assess student achievement. In order to assess teacher attitudes, teachers completed a questionnaire that included efficacy questions, forced-choice measure questions, multiple personal teaching efficacy vignettes, questions about stress levels while teaching, and a question concerning their responsibility for their student's learning. 
Three instruments were used to collect data during classroom observations. The Climate and Control System was used to measure the climate of the classroom, Teacher Practices Observation Record was used to measure instructional styles, and Engagement Rate Form was used to measure student attentiveness. Five observers were trained in the use of each of the instruments listed above over an intensive 2-month period. Ashton and Webb found a statistically significant relationship between student achievement in mathematics and a teacher's sense of self- efficacy. However, they did not find a similar relationship between student achievement in reading and a teacher's sense of personal efficacy. In conclusion, the researchers found that a teacher's sense of efficacy is an important variable when it comes to student achievement, but this importance may vary depending on the subject being taught.

Both Bandura (1997) and Ashton and Webb (1986) emphasize that teacher selfefficacy is an important factor when it comes to influencing student learning. Bandura (1997) claims that since teachers are responsible for providing students with a positive learning environment, teachers should be confident in their ability to create those learning spaces and their ability to affect student learning. Ashton and Webb (1986) showed the importance of teachers' self-efficacy when teaching certain subjects, such as mathematics, where teachers with higher self-efficacy had much more of an impact on student learning than teachers with lower self-efficacy. While developing a teacher's self-efficacy is important, Tschannen-Moran, Hoy and Hoy (1998) address the various instruments that have been used to assess self-efficacy over the years, which leads them to recommend that future self-efficacy research should focus on more interpretive case studies to further clarify the process of developing self-efficacy. 
Enhancing Teacher Efficacy through Professional Development.

Lakshmanan et al. (2011) examined the effect that standards-based professional development had on teacher self-efficacy and instructional practices of elementary and middle school science teachers. Over the course of 3 years, teachers were offered content courses and the ability to join professional learning communities. Form A of the Science Teaching Efficacy Belief Instrument (STEBI-A) was administered on five occasions to assess teacher self-efficacy, while instructional practices was evaluated four times with classroom observations using the Reformed Teacher Observation Protocol (RTOP). Over the 3-year period, this standards-based professional development program had a positive impact on both teacher self-efficacy and implementation of inquiry-based instruction in the classroom. Also, a positive correlation was observed between the growth in selfefficacy and the level of inquiry-based instruction that was applied in the classroom. These conclusions help to emphasize the importance of targeting self-efficacy as well as instructional practices when designing effective professional development programs.

Sandholtz and Ringstaff (2013) discuss how very few elementary teachers have a strong background in science and are not given the chance to expand their science knowledge and skills as teachers due to the lack of professional development for elementary teachers. This on-going study investigates the extent to which teacher professional development leads to changes in early elementary science instruction by examining science content knowledge, self-efficacy in teaching science, and science related instructional practices among teachers who participated in a three year program. The Science Teaching Efficacy Beliefs Instrument (STEBI) was administered prior to the 
program and in the spring of each academic year to collect data on teacher self-efficacy. Tests were administered 3 times a year to measure content knowledge as teachers progressed through the program. Classroom observations of a subsample of teacher participants were set up to examine changes in instructional practices. Follow-up interviews provided additional data about self-efficacy, curricular choices, and instructional strategies. This study found significant positive changes in content knowledge, implementation of instructional practices in science, and self-efficacy in teaching science. These changes were more pronounced in the first year of the program, but the second year was crucial in order to sustain these positive changes. This suggests that important gains can be achieved in short-term targeted professional development programs, but they are not sufficient for continued change, creating a need for sustained professional development programs.

Sandholtz and Ringstaff (2014) examined how participation in a 3-year professional development program by K-2 teachers influenced self-efficacy and changed science instruction. Thirty-nine K-2 teachers participated in the entire study and represented 16 rural school districts in Northern California. Each summer participants attended a 6-day institute where teachers received adult level science content instruction, pedagogical training focused on science instruction, and a chance for teacher collaboration. Teachers participated in additional sessions and follow-up activities in the following school years in-between summer sessions. The researchers administered the Science Teaching Efficacy Beliefs Instrument (STEBI) and a survey for teachers before the program, as well as in the spring before the end of each school year. Interviews and classroom observations were also conducted in order to provide additional data about 
teacher's beliefs and science instruction. Sandholtz and Ringstaff found that overall teacher self-efficacy, personal science teaching efficacy and outcomes efficacy significantly increased from the beginning of the program to the end. In conclusion the results suggest that teacher's self-efficacy is an important factor when teaching science at the elementary level.

A series of studies by Sandholtz and Ringstaff $(2013,2014)$ have demonstrated that although short-term professional development programs may have some beneficial effect in improving teacher knowledge and self-efficacy in teaching science, only longterm professional development experiences, extending for two years or more, is likely to make lasting changes in teachers' self-efficacy and classroom behaviors. Lakshmanan et al. (2011) found that when designing PD programs, it is important to target both a teacher's self-efficacy and instructional practices in order to bring about significant changes over the course of the PD experience. Keeping all of this in mind can help to further develop effective PD programs.

Improving Self-Efficacy in Outdoor Education through Professional Development Holden et al. (2011) discusses how environmental studies (ES) have become an important part of K-12 curricula and the challenges many teachers encounter when trying to implement outdoor ES practices. This paper examines the changes in self-efficacy and outcome expectancy among K-12 teachers who participated in a two week, field intensive professional development (PD) program. The investigators used multiple qualitative and quantitative measures to assess participant efficacy. A modified version of an efficacy measurement instrument, the Science Teaching Efficacy Belief Instrument (STEBI), was 
administered at the beginning and end of the PD experience. Various assessments during the PD experience, such as teacher's reflective journals, Venn diagrams comparing indoor and outdoor science instruction, and recorded group discussions about the use of outdoor spaces for learning, were used to validate the data collected from the modified STEBI instrument. The results concluded that positive PD experiences led to an improvement in self-efficacy among participants. The researchers applied the results of this study, as well as new questions that arose, to plan better PD experiences for the future.

Moseley, Huss, and Utley (2010) introduces the fact that many teachers believe it is important to provide outdoor learning experiences to their students but previous studies have found that teachers have low expectations about their ability to teach students effectively in an outdoor setting. The researchers set out to determine what effect an intensive two-week summer earth systems science professional development program had on environmental education teacher self-efficacy of thirty-eight K-12 teachers. The Global Learning and Observations to Benefit the Environment (GLOBE) curriculum was used as a framework for the program. In addition to attending the two-week summer session, teachers participated in one orientation session, two follow up seminars, and were required to create an action implementation plan that included GLOBE protocols and activities. In order to measure a change in teacher efficacy the researchers created a modified version of the Science Teaching Efficacy Beliefs Instrument- Form B (STEBI-B), which they named the Environmental Education Efficacy Belief Instrument (EEEBI). The EEEBI allowed the researchers to assess changes in personal environmental teaching efficacy (PETE) and environmental teaching outcome expectancy (ETOE). Moseley et al. found that participation in the two-week intensive workshop did significantly increase teachers' 
PETE and ETOE scores. However, there was no significant change in PETE or ETOE scores after the five-month period that followed the two-week intensive workshop. The researchers recommended that future research should be done to look at how teaching efficacy changes as novice teachers gain more experience and how environmental education teaching efficacy beliefs affects student achievement.

According to Holden et al. (2011) environmental education is becoming a larger part of K-12 curricula and teachers believe it is important to incorporate more outdoor experiences into their lessons. This study points out that many teachers however do not feel confident in their ability to teach effectively in an outdoor setting. Holden et al. found that a field intensive two-week professional development program was successful in improving teacher self-efficacy in teaching environmental science outdoors. However, as illustrated by Mosely, Huss, and Utley (2010), a two-week professional development program based on the GLOBE program was not successful. These findings, in which one program was successful and the other was not, suggest that program content, quality, instructors, or other factors are critical in improving teacher self-efficacy. More research on this topic could help to determine what is needed to create an effective professional development program that positively affects teacher's confidence in teaching outdoors.

Importance of Pedagogical Content Knowledge

Van Driel, Verloop,and de Vos (1998) examine the concept of pedagogical content knowledge $(\mathrm{PCK})$ in regards to science teaching. They attempt to define the concept of PCK but ultimately they demonstrate that there isn't a universally accepted definition of PCK. Through reviewing various research studies on science teacher's PCK, the authors 
found that being familiar with a specific topic combined with teaching experience positively affects PCK. The authors then present a study that focused on developing PCK of chemistry teachers on chemical equilibrium. The aim of the study was to improve the participant's ability to recognize students' preconceptions and difficulties associated with learning about chemical equilibrium. Twelve participants attended an in-service workshop that focused on an experimental course, which was then implemented by the participants in their classrooms. The authors collected data through recording all workshop sessions, collecting participants' written responses to assignments during the workshop, distribution of a questionnaire, and classroom recordings from two of the participants. Many of the participants indicated that by discussing the topic with students and listening to student reasoning they were able to improve their understanding of student conceptions. As a result of this study, the authors gained insight into how chemistry teachers transform their pedagogical content knowledge of chemical equilibrium in order to help student understanding of the topic.

Cochran (1991) presents a brief overview of pedagogical content knowledge (PCK) and describes a tentative model for use in teacher preparation programs. The author reviews many studies that have shown that PCK is much more than subject matter knowledge, is very specific to the concepts that are being taught, and develops over time with added experience. PCK is unique to teachers and differs from other types of knowledge since it requires teachers to integrate their subject matter knowledge into what they know about teaching. In order for teachers to successfully accomplish this integration, they must have two important areas of knowledge that is specific to teachers. One is the knowledge of their students, which includes students' abilities, learning 
strategies, attitudes, motivations, prior knowledge and any misconceptions that they may have. The second component is the understanding of environments, such as social, physical, and cultural, in which students learn. The author began a theoretical and philosophical analysis of teacher preparation at the University of Northern Colorado. Seven teams were created that included faculty and administrators from the colleges of Arts and Sciences, Education, and Health and Human services. These seven teams participated in a one-week retreat that focused on redesigning teacher education. The authors of this paper were part of one team that was focused on PCK and how it might be applied to the education of teachers. Four areas of PCK were defined and included the following: content knowledge, pedagogical knowledge, knowledge of students, and knowledge of the school environment. The author outlines a number of working hypotheses with the hopes of promoting discussion and future research projects that lead to improvement of developing teachers' PCK.

As shown by Van Driel, Verloop and de Vos (1998), high school teachers, who may already be familiar with the content of their subject (chemistry), can improve their PCK by learning about their students' common misconceptions and learning difficulties, as well as discussing ideas with students and listening to student reasoning. Cochran (1991) defined PCK somewhat more broadly than other studies, to include four areas: 1) content knowledge, 2) pedagogical (teaching) knowledge; 3) knowledge of their students' abilities, learning strategies, attitudes, motivations, prior knowledge, and misconceptions, and 4) knowledge of the school environment. These studies help to demonstrate that teachers who have strong PCK can instruct their students in a way that enhances student learning. 
Enhancing Teacher's Pedagogical Content Knowledge

Many elementary school teachers are hesitant to teach science due to a lack of confidence that tends to arise from limited knowledge of science subject matter, specifically the knowledge of how to make science content relevant and available to their students. Appleton (2008) presents case studies of two elementary teachers that participated in a professional development program that focused on developing science pedagogical content knowledge (PCK) by providing support by a mentor. The participants attended a 2-day workshop focused on the new science curriculum that was being adopted in the participants' schools. Data sources included tape-recorded interviews of participants, field notes of lessons, and some videotaped lessons. The mentor supported the participants for the length of an entire science unit in the teacher's classrooms, varying from 6-8 weeks. Through the mentoring process, the mentor assumed the role of a critical friend in joint planning and teaching. Appleton found that through the mentoring process, the participants improved their science PCK. Even though the participant's science content knowledge had not significantly increased, their confidence in their ability to access science content that was needed and adapt that science content to their teaching knowledge was positively influenced.

Pecore, Kirchgessner and Carruth (2013) studied a unique PD experience that took place at Zoo Atlanta and contained collaborated lessons between zoo personal and faculty from Georgia State University's College of Education and Neuroscience Institute. The authors examined what kind of impact this unique PD experience had on teacher content knowledge, attitudes and classroom lessons. Over the course of seven years, 103 teachers 
participated in the Animal Behavior and Brain PD program. The workshop included 35 hours of face-to-face participation over the course of one week, as well as the production of a final lesson plan by each teacher and a final follow up session in the fall after the summer course. The program utilized three instructional methods to teach the information: field trips, direct instruction and discussion, and teacher co-planning. The researchers collected data through a 20 question pre and posttest to assess content knowledge, a demographic survey, a pre and post attitude survey, evaluation of lesson plans, and recorded reflections. The data analysis showed a statistically significant increase in content knowledge among participants. The researchers concluded that providing a PD program in an enjoyable and interactive learning environment that provides authentic learning experiences, collaborates with science professionals, and allows for teachers to incorporate new content into lesson plans through co-planning will improve teacher's science content knowledge and maintain positive attitudes towards science.

A study by Appleton (2008) showed that through a mentoring based PD program a teacher's PCK can be positively influenced by helping participants gain the skills needed to adapt science content to their teaching. Pecore, Kirchgessner, and Carruth (2013) found that providing authentic learning experiences in an interactive learning environment can significantly improve teacher's content knowledge and their ability to successfully integrate new content into lesson plans.

\section{Summary}

Many studies have shown that a teacher's self-efficacy and PCK are important factors when it comes to student learning. Learning experiences that take place outside of 
the classroom can help to enhance science lessons by making them more authentic and relevant. Creating out-of-school learning experiences can be difficult due to the fact that teacher's lack the self-efficacy and/or PCK to incorporate outdoor learning into their science lessons. A number of studies have looked at how different PD programs have influenced teacher's self-efficacy and PCK, but there have been only a few that have looked at PD experiences that have incorporated learning that takes place outside the classroom.

My research on the Connect2Science workshops will lend a new perspective to how unique PD programs can influence teacher's self-efficacy and PCK. This study will hopefully help others to understand how nature based PD programs can be used to help enhance both the self-efficacy and PCK of participants who are looking to incorporate the outdoors into their formal science curriculum. 
Chapter 3: Methods

Overview

The focus of this case study was a free outdoor, nature based professional development workshop series at Tryon Creek State Park called Connect2Science. I attended all of the Connect2Science workshops as a co-instructor. In the role of coinstructor I helped to plan each workshop, organize activities, and gather any other necessary materials for that day. The research question for this study was: In what ways does the Tryon Creek Connect2Science professional development workshop influence teachers': a) self-efficacy in teaching science outdoors and b) science pedagogical content knowledge?

The Connect2Science PD workshop was the independent variable for this study. Through this series of workshops, participants learned about new ways to incorporate outdoor activities into their science curriculum. Over the course of five workshops, inservice elementary teachers experienced various hands-on activity demonstrations as well as used conceptual probes to help them discover any misconceptions that they might have about various life science topics. Each of the five workshops was different, and teacher participants were able to attend any number of the five workshops.

There were two dependent variables for this research study. The first was teacher self-efficacy. In order to measure self-efficacy, participants were given a retrospective pre and post survey. The second independent variable was the participants' pedagogical content knowledge (PCK). PCK was assessed with a pre and post reflection exercise that was scored using a rubric adapted from a rubric developed by the Portland Metro Stem 
Partnership in attempt to create a common measurement system (Saxton et al., 2014).

Semi-structured interviews were conducted as a way to supplement the other data collected by the self-efficacy survey and PCK reflection. These interviews provided a richer understanding of the change in participants' self-efficacy and PCK over the course of the workshops. I predicted that participants would see an increase in their confidence level to take students outside for science lessons and that they gained some new pedagogical content knowledge that will help to improve their science instruction. I also expected that teachers who attended more of the workshops would have greater increase in self-efficacy and PCK than those who attended fewer. However, I was open to other possible outcomes that may arise.

An outline of the treatment, survey, and interviews is included below:

Table 1. Workshop Treatment Outline

\begin{tabular}{|llllllllll|}
\hline $\mathrm{N}_{\mathrm{A}}$ & $\mathrm{X}$ & $\mathrm{X}$ & $\mathrm{X}$ & $\mathrm{X}$ & $\mathrm{X}$ & $\mathrm{O}_{1}$ & $\mathrm{O}_{2}$ & $\mathrm{O}_{3}$ & $\mathrm{O}_{4}$ \\
\hline $\mathrm{N}_{\mathrm{B}}$ & $\mathrm{X}$ & $\mathrm{X}$ & $\mathrm{X}$ & $\mathrm{X}$ & $\mathrm{X}$ & $\mathrm{O}_{1}$ & $\mathrm{O}_{2}$ & $\mathrm{O}_{3}$ & $\mathrm{O}_{4}$ \\
\hline $\mathrm{N}_{\mathrm{C}}$ & $\mathrm{X}$ & $\mathrm{X}$ & $\mathrm{X}$ & $\mathrm{X}$ & $\mathrm{X}$ & $\mathrm{O}_{1}$ & $\mathrm{O}_{2}$ & $\mathrm{O}_{3}$ & $\mathrm{O}_{4}$ \\
\hline $\mathrm{N}_{\mathrm{D}}$ & $\mathrm{X}$ & $\mathrm{X}$ & $\mathrm{X}$ & $\mathrm{X}$ & $\mathrm{X}$ & $\mathrm{O}_{1}$ & $\mathrm{O}_{2}$ & $\mathrm{O}_{3}$ & $\mathrm{O}_{4}$ \\
\hline $\mathrm{N}_{\mathrm{E}}$ & & & $\mathrm{X}$ & $\mathrm{X}$ & $\mathrm{X}$ & $\mathrm{O}_{1}$ & $\mathrm{O}_{2}$ & $\mathrm{O}_{3}$ & $\mathrm{O}_{4}$ \\
\hline
\end{tabular}

$\mathrm{N}_{\mathrm{x}}=$ Participants

$\mathrm{X}=$ Treatment (Connect2Science full-day workshop)

$\mathrm{O}_{1}=$ pre-test survey

$\mathrm{O}_{2}=$ post-test survey

$\mathrm{O}_{3}=$ reflection piece

$\mathrm{O}_{4}=$ interview

Participants

The sample size for this study is five participants. As seen in the diagram above four of the five participants attended all five workshops while the remaining one 
participant attended three of the five workshops.

In-service elementary teachers voluntarily signed up for the Connect2Science workshops that were promoted on the Tryon Creek State Park's website. Over the course of all five workshops, we saw a total of fourteen different teachers. These fourteen teachers were most likely motivated individuals who were looking to improve their teaching and incorporate more outdoor education into their everyday lessons. These inservice teachers were from different schools and districts in the Portland metropolitan area. The level of instruction ranged from kindergarten up to sixth grade. All participants of the Connect2Science experience were invited to be a part of this study at the conclusion of the workshop series. 
Table 2. Overview of Participants

\begin{tabular}{|c|c|c|c|c|}
\hline Participant & $\begin{array}{c}\text { School } \\
\text { Description }\end{array}$ & $\begin{array}{l}\text { Students receiving } \\
\text { free/reduced lunch }\end{array}$ & $\begin{array}{l}\text { Grade } \\
\text { Taught }\end{array}$ & Participant Description \\
\hline Teacher A & $\begin{array}{l}\text { a independent } \\
\text { nonprofit } \\
\text { middle school } \\
\text { for students } \\
\text { with learning } \\
\text { differences } \\
\end{array}$ & $*$ & $5^{\text {th }} / 6^{\text {th }}$ & $\begin{array}{l}\text { Inclusive teacher for } 5^{\text {th }} \text { and } \\
6^{\text {th }} \text { grade. Incorporates } \\
\text { science and outdoor lessons } \\
\text { daily if weather permits. }\end{array}$ \\
\hline Teacher B & $\begin{array}{l}\text { A middle school } \\
\text { in the Newburg } \\
\text { School District } \\
\text { that has grades } \\
6-8 \text {. }\end{array}$ & $39.3 \%$ & $6^{\text {th }}$ & $\begin{array}{l}\text { A resource teacher that } \\
\text { specializes in math but also } \\
\text { focuses on helping children } \\
\text { with physical or educational } \\
\text { learning difficulties. Very } \\
\text { little time teaching science. }\end{array}$ \\
\hline Teacher C & $\begin{array}{c}\text { An elementary } \\
\text { school in the } \\
\text { Hillsboro } \\
\text { School District } \\
\text { that has grades } \\
\mathrm{K}-6 \text {. }\end{array}$ & $51.9 \%$ & $5^{\text {th }}$ & $\begin{array}{l}\text { English / Spanish dual } \\
\text { language immersion teacher. } \\
\text { Has } 15 \text { years teaching } \\
\text { experience. Took students } \\
\text { on field trips, but did not } \\
\text { incorporate outdoor learning } \\
\text { on a regular basis. }\end{array}$ \\
\hline Teacher D & N/A & N/A & $3^{\text {rd }}$ & $\begin{array}{c}\text { Was on a leave of absence } \\
\text { while attending the } \\
\text { workshops to spend time at } \\
\text { home with her kids. } \\
\text { Previously taught } 3^{\text {rd }} \text { grade } \\
\text { in Clackamas before taking } \\
\text { leave. Hard time fitting } \\
\text { science into daily lesson } \\
\text { plans. Minimal outdoor } \\
\text { learning incorporated in } \\
\text { curriculum. }\end{array}$ \\
\hline Teacher E & $\begin{array}{l}\text { An elementary } \\
\text { school in the } \\
\text { North } \\
\text { Clackamas } \\
\text { School District } \\
\text { that has grades } \\
\text { K- } 5 \text {. }\end{array}$ & $23 \%$ & K & $\begin{array}{l}\text { First year teaching. Was half } \\
\text { time and is moving to full } \\
\text { time for next school year. } \\
\text { Science is integrated into } \\
\text { inclusive language } \\
\text { curriculum. Rarely takes } \\
\text { students outdoors for } \\
\text { lessons. }\end{array}$ \\
\hline
\end{tabular}


Treatment

The Connect2Science workshops occurred every third Saturday during the months of October, November, January, February, and May. Each full-day workshop concentrated on a general concept. The broad concepts that were covered were: animals, the sun, water, soil and plants. Each workshop contained hands-on activities that utilized two instructional practices used to teach in an outdoor environment. These practices are outlined in Teaching for Conceptual Understanding in Science (Konicek-Moran \& Keeley, 2015). They were used throughout the workshops to demonstrate effective strategies while teaching science outdoors. The instructional practices that were used were ABCCBV (Activity Before Concept, Concept Before Vocabulary) and Predict-ObserveExplain Sequences.

The instructional practices that were emphasized complimented the use of some of the NGSS science practices, such as asking questions based off of observations and conducting investigations. All of the activities throughout the day implemented both instructional practices mentioned in the above paragraph, as well as incorporating the use of a couple of the science practices defined in NGSS. These instructional practices and science practices were centered on a broad topic that was assigned to each workshop. As an example, the first workshop focused on the broad topic of animals. This large concept allowed us to take many different directions in our instruction throughout the day. All of the performance expectations from the Next Generation Science Standards that can be applied to animals were laid out for participants. Appendix B includes a summary table of the content covered in each workshop, as well as the disciplinary core ideas and essential 
questions that were pulled from the Next Generation Science Standards.

Along with hands-on activities that could be done in the classroom, activities and small nature walks occurred throughout each workshop. Since the goal of the Connect2Science workshops were to build participants' self-efficacy and PCK in relation to learning science in an outdoor education setting, all classroom activities and topics had various outdoor experiences to provide multiple learning opportunities.

Throughout the workshops, participants were given formative assessment probes, mostly developed by Page Keeley in her series Uncovering Student Ideas in Life Science (Keeley, 2011). Participants completed the probes just like their students would, followed by a discussion of the information contained in the probe. This helped to draw out any misconceptions that the participants themselves might have while also giving them a chance to see what kind of misconceptions their students may hold.

Instruments

Pedagogical content knowledge reflection. PCK was assessed using a reflection piece that was administered at the start of the final workshop on plants. At the start of the workshops participants were given a Page Keeley probe, which is included in appendix B. After looking over the probe, participants were asked to write a quick reflection that addressed which prompt they agreed with, any misconceptions that they think students may hold related to the probe topic, and activities that they would use to help address those misconceptions. Once the participants were done writing the short reflection piece, there was a group discussion about the probe. I compared each reflection with the teacher notes provided by Page Keeley for the Apple Tree probe as well as common misconceptions identified by Project 2061 through the American Association for the 
Advancement of Science to assess how deeply the participants had thought about the different misconceptions.

Self-efficacy Survey. Self-efficacy was measured by a retrospective pre and post self-efficacy survey that was developed by the Portland Metro STEM Partnership based on research done by Tschannen-Moran and Hoy (2001) and Siwatu (2007). This survey consists of 33 questions that are divided into 4 efficacy subscales: efficacy for student engagement, instructional practice, classroom management, and culturally relevant pedagogy. Participants were asked to respond twice, using a 9-point Likert scale, to each question, in order to demonstrate where they believed they were at the start and at the end of the Connect2Science program. This survey can be seen in appendix A.

Interviews. Interviews were used to assess self-efficacy and PCK. The Interviews were scheduled at convenient times for participants after the conclusion of all five Connect2Science workshops. The interview included seven questions, with possible follow up questions listed as well. A few questions concentrated on self-efficacy and others focused more on the participants' PCK. Interview questions that were asked are listed below.

1. Why did you enroll in the workshops? What did you hope to gain from them?

2. Now that you have completed $X$ workshops, how would you summarize what you learned?

3. Before attending these workshops did you typically take students outdoors for science lessons?

a) If yes, how often would you take your students outside for these lessons?

b) If yes, were there any challenges you had to overcome to gain the confidence to take your students outside for science lessons? If so what were they? How did you overcome them?

c) If no, why not? 
4. How confident are you currently in taking students outdoors for learning experiences?

a) Did the workshop affect your confidence in any way? How so?

b) How often do you see yourself taking your students outside for science related lessons in the future?

c) Was there anything specific about the workshop that made a difference for you?

d) We talked about many common misconceptions students may have concerning a range of topics and some activities that could be used to help correct those misconceptions. What misconceptions did the workshops help you identify that students may hold that you had not thought about before? What were some common misconceptions you had before attending the Connect2Sceience workshops?

6. Tell me how you are going to incorporate the outdoors into your instruction now that you have been through $\mathrm{X}$ workshops?

a) Was there anything that stood out that you think your students would really connect with?

b) Was there a certain moment during the workshops that helped you envision a way to use the outdoors to explain a concept better to your students?

7. Before we end this interview, do you have any other comments or last remarks concerning your experience with the Connect2Science program?

Procedures

This study took place over the course of eight months, with a total of five professional development workshops. The aim of each workshop was to familiarize participants with the Next Generation Science Standards as well as introduce ways to incorporate the outdoors into formal science instruction that related back to the standards. Each workshop consisted of hands-on activities and information that focused on a broad topic related to science.

Before the start of the final workshop, participants were invited to be a part of this study. If participants choose to take part, they were walked through a reflection exercise to assess PCK and given the retrospective pre and post self-efficacy survey. Interviews happened over the course of a month following the last workshop as participants had time. 
Once all of the data was collected and organized, I compared the information obtained from the interviews to the information from the survey and reflection pieces in order to see if they supported one another.

For those participants that had attended previous workshops but were not at the last one, I attempted to contact them by email to invite them to be a part of the study. Unfortunately, I only received one response, which did not work out in the end. 


\section{Chapter 4: Results}

The results are organized according to the different instruments used to assess the various components researched in this study.

Self-efficacy survey. The retrospective self-efficacy surveys were analyzed by adding up the score for each participant in each of the four subcategories for both the pre and post results. The sums for each category are shown in Table 3.

Table 3. Participant's Pre and Post Self-Efficacy Sums

\begin{tabular}{|c|c|c|c|c|c|c|c|c|}
\hline Participant & PRE & POST & PRE & POST & PRE & POST & PRE & POST \\
\hline A & 67 & 70 & 72 & 72 & 59 & 66 & 63 & 64 \\
\hline B & 45 & 58 & 62 & 66 & 47 & 59 & 62 & 68 \\
\hline C & 40 & 51 & 49 & 51 & 50 & 58 & 56 & 58 \\
\hline D & 45 & 59 & 59 & 60 & 45 & 60 & 57 & 63 \\
\hline E & 50 & 58 & 50 & 56 & 39 & 57 & 50 & 59 \\
\hline
\end{tabular}

\begin{tabular}{|l|l|}
\hline Key & Student Engagement \\
\hline \multirow{n}{*}{} & Instructional Practice \\
\cline { 2 - 2 } & Classroom Management \\
\cline { 2 - 2 } & Culturally Relevant Pedagogy \\
\cline { 2 - 2 }
\end{tabular}

Once the sums of the pre and post results were calculated, I chose to use the Wilcoxon Rank Sum Test, which is a non-parametric statistical hypothesis test, to determine whether any changes in scores were statistically significant. The Wilcoxon Rank Sum Test is used for samples where it cannot be assumed that the data is normally distributed, which is true for my small sample size. For this analysis I let $\mu_{1}=$ before group and $\mu_{2}=$ after group. The null hypothesis was $H_{0}: \mu_{1}-\mu_{2} \geq 0$ or $\mu_{1} \geq \mu_{2}$, where the alternative hypothesis was $\mathrm{H}_{\mathrm{A}}: \mu_{1}-\mu_{2}<0$ or $\mu_{1}<\mu_{2}$. Using this test, I ran the sums of each subcategory separately in order to see if there was a statistically significant difference between the pre and post scores. The instructional practice sub-category had the best p- 
value of all four self-efficacy constructs, followed by the student engagement subcategory. While the culturally relevant sub-category showed a change, the p-value is very high, indicating that the change was not as significant as those seen in the instructional practice and student engagement categories. The results are shown in Figure 1. 
Figure 1. Statistical Analysis of Self-Efficacy Constructs

Student Engagement
\begin{tabular}{|l|r|}
\hline \multicolumn{2}{|c|}{ Data } \\
\hline Level of Significance & $\mathbf{0 . 0 5}$ \\
\hline \multicolumn{2}{|c|}{ Population 1 Sample } \\
\hline Sample Size & 5 \\
\hline Sum of Ranks & 19 \\
\hline \multicolumn{2}{|c|}{ Population 2 Sample } \\
\hline Sample Size & 5 \\
\hline Sum of Ranks & 36 \\
\hline \multicolumn{2}{|c|}{ Lower-Tail Test } \\
\hline Lower Critical Value & $\mathbf{- 1 . 6 4 4 9}$ \\
\hline $\boldsymbol{p}$-Value & $\mathbf{0 . 0 3 7 9}$ \\
\hline \multicolumn{2}{|c|}{ Reject the null hypothesis } \\
\hline
\end{tabular}

\begin{tabular}{|c|c|}
\hline \multicolumn{2}{|c|}{ Classroom Management } \\
\hline \multicolumn{2}{|c|}{ Data } \\
\hline Level of Significance & $\overline{0.05}$ \\
\hline \multicolumn{2}{|c|}{ Population 1 Sample } \\
\hline Sample Size & 5 \\
\hline Sum of Ranks & 24.5 \\
\hline \multicolumn{2}{|c|}{ Population 2 Sample } \\
\hline Sample Size & 5 \\
\hline Sum of Ranks & 30.5 \\
\hline \multicolumn{2}{|c|}{ Lower-Tail Test } \\
\hline Lower Critical Value & -1.6449 \\
\hline$p$-Value & 0.2654 \\
\hline \multicolumn{2}{|c|}{ Do not reject the null hypothesis } \\
\hline
\end{tabular}

\begin{tabular}{|c|c|}
\hline \multicolumn{2}{|c|}{ Instructional Practice } \\
\hline \multicolumn{2}{|c|}{ Data } \\
\hline Level of Significance & 0.05 \\
\hline \multicolumn{2}{|c|}{ Population 1 Sample } \\
\hline Sample Size & 5 \\
\hline Sum of Ranks & 17.5 \\
\hline \multicolumn{2}{|c|}{ Population 2 Sample } \\
\hline Sample Size & 5 \\
\hline Sum of Ranks & 37.5 \\
\hline \multicolumn{2}{|c|}{ Lower-Tail Test } \\
\hline Lower Critical Value & -1.6449 \\
\hline$p$-Value & 0.0184 \\
\hline Reject the null & \\
\hline
\end{tabular}

\begin{tabular}{|l|r|}
\begin{tabular}{|l|r|}
\hline \multicolumn{2}{|c|}{ Dutta } \\
\hline Level of Significance & $\mathbf{0 . 0 5}$ \\
\hline \multicolumn{2}{|c|}{ Population 1 Sample } \\
\hline Sample Size & 5 \\
\hline Sum of Ranks & 19.5 \\
\hline \multicolumn{2}{|c|}{ Population 2 Sample } \\
\hline Sample Size & 5 \\
\hline Sum of Ranks & 35.5 \\
\hline \multicolumn{2}{|c|}{ Lower-Tail Test } \\
\hline Lower Critical Value & $\mathbf{- 1 . 6 4 4 9}$ \\
\hline $\boldsymbol{p}$-Value & $\mathbf{0 . 0 4 7 3}$ \\
\hline \multicolumn{2}{|c|}{ Reject the null hypothesis } \\
\hline
\end{tabular}
\end{tabular}

Pedagogical Content Knowledge Reflection. All participants chose the correct answer for the formative assessment probe in their reflection piece, demonstrating that none of the participants held a common misconception themselves. The misconceptions and instructional strategies that each participant wrote down are outlined in Table 4. 
Table 4. Pedagogical Content Knowledge Reflection Summary

\begin{tabular}{|c|c|c|c|}
\hline Participant & $\begin{array}{l}\text { Misconceptions and instructional } \\
\text { practices from reflections }\end{array}$ & $\begin{array}{c}\text { \# of } \\
\text { misconceptions } \\
\text { identified }\end{array}$ & $\begin{array}{c}\# \text { of instructional } \\
\text { strategies to address } \\
\text { misconceptions }\end{array}$ \\
\hline A & $\begin{array}{l}\text { Misconception: Parts of plants. } \\
\text { Students need to look at plants as } \\
\text { parts - understanding different roles } \\
\text { and what they do. } \\
\text { Knowing the parts of a plant would } \\
\text { be helpful to teach. I would use } \\
\text { individual lessons on plant parts - } \\
\text { also models and hands on } \\
\text { experiments to solidify info. Act out } \\
\text { different tree parts. }\end{array}$ & 1 & 1 \\
\hline B & $\begin{array}{l}\text { Misconception: Trees absorb } \\
\text { nutrients (food) from the ground. }\end{array}$ & 1 & 0 \\
\hline $\mathrm{C}$ & $\begin{array}{l}\text { Misconception: Some students might } \\
\text { agree with Molly since trees draw } \\
\text { minerals /nutrients through the root } \\
\text { system as well as water. } \\
\text { Each of the friends refers to an } \\
\text { element of the tree structure that } \\
\text { plays a part in the part of the growth } \\
\text { and survival of the tree, so each } \\
\text { could be used to show how it is } \\
\text { related to the central process of } \\
\text { photosynthesis. }\end{array}$ & 1 & 1 \\
\hline D & $\begin{array}{l}\text { Misconception: Molly's idea about } \\
\text { food being made in the roots is a } \\
\text { common misconception students } \\
\text { have - they often think plants suck } \\
\text { food up through their roots. } \\
\text { Misconception: some students } \\
\text { initially struggle with the idea that } \\
\text { plants make their own food, like } \\
\text { Jared's idea. }\end{array}$ & 2 & 0 \\
\hline $\mathrm{E}$ & $\begin{array}{l}\text { Misconception: It could be confusing } \\
\text { that an apple tree makes our "food" } \\
\text { but that it uses a different process and } \\
\text { requires different things to produce } \\
\text { its own food. } \\
\text { To untangle this misconception I } \\
\text { would compare humans and plants, } \\
\text { perhaps using a plant that does not } \\
\text { produce a well-known human food as } \\
\text { the comparison. For instance, } \\
\text { introducing the prompt 'humans eat } \\
\text { (food) to live but plants need } \\
\text { (sun, water, } \\
\text { nutrients, air) to make their own } \\
\text { food. }\end{array}$ & 1 & 1 \\
\hline
\end{tabular}


After reading each reflection piece, I made note of how many misconceptions each participant outlined and compared these to the common misconceptions defined by Page Keeley in the teacher notes for the probe, as well as any defined by Project 2061 through the American Association for the Advancement of Science. The misconceptions defined by both of these sources, along with what Page Keeley said should be addressed when teaching photosynthesis in order to address student misconceptions are laid out in Table 5.

Table 5. Common Student Misconceptions

\begin{tabular}{|c|c|}
\hline Common Student Misconceptions & $\begin{array}{l}\text { Topics that should be covered in order to } \\
\text { address common misconceptions }\end{array}$ \\
\hline 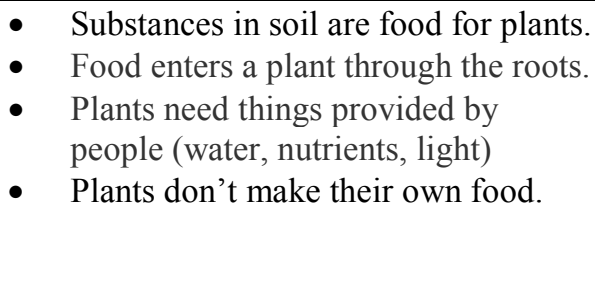 & $\begin{array}{l}\text { - } \begin{array}{l}\text { Plants need water, sunlight, nutrients } \\
\text { and air }\end{array} \\
\text { Plants have structures for getting } \\
\text { water (roots) and capturing sunlight } \\
\text { (leaves) } \\
\text { Introduce idea that plants make their } \\
\text { own food }\end{array}$ \\
\hline
\end{tabular}

Interviews. Once the interviews were completed, interview data that expanded on the influence of the workshops on participant's self-efficacy were organized into a table. Only data that helped to expand on the self-efficacy constructs that showed a significant change over the course of the workshops were focused on, those being instructional practices and student engagement. The interview data used is represented in the Table 6. 
Table 6. Supporting Interview Data for Self-Efficacy Constructs

\begin{tabular}{|c|c|c|}
\hline $\begin{array}{c}\text { Self-Efficacy } \\
\text { Construct }\end{array}$ & $\begin{array}{l}\text { \# of participants } \\
\text { who mentioned it } \\
\text { in interview }\end{array}$ & Sample Quotes \\
\hline \multirow{4}{*}{$\begin{array}{l}\text { Instructional } \\
\text { Practice }\end{array}$} & \multirow{4}{*}{ 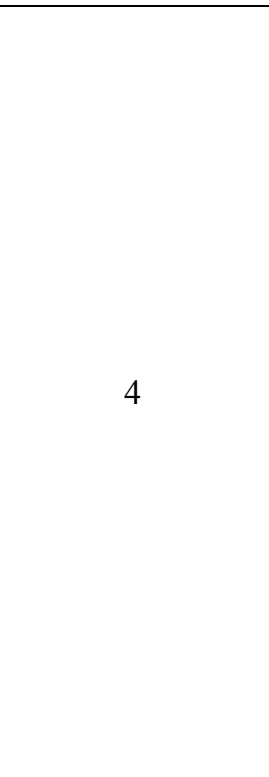 } & $\begin{array}{l}\text { ".....where you are actually doing some of the fun lessons. } \\
\text {...to actually participate in the activities as if we were a class } \\
\text { was really important and really fun. I really liked that a lot } \\
\text { and having that chance during that lesson to make the } \\
\text { mistakes that kids are going to make and then talk about what } \\
\text { would you do with that" - Teacher A }\end{array}$ \\
\hline & & $\begin{array}{l}\text { "I like doing the activities, not just reading about them or } \\
\text { getting a book or packet about them."-Teacher D }\end{array}$ \\
\hline & & $\begin{array}{l}\text { "I think being with other educators and being in a position of } \\
\text { being a learner was very helpful. I always need to have that } \\
\text { empathy with kids and I need to do it myself because it's } \\
\text { going to help me be a better teacher." - Teacher B }\end{array}$ \\
\hline & & $\begin{array}{c}\text { "I liked how the workshops got the teachers outside } \\
\text { exploring, which made me realize that students need to get } \\
\text { out as well to explore and investigate." } \\
\text {-Teacher C }\end{array}$ \\
\hline \multirow[t]{2}{*}{$\begin{array}{c}\text { Student } \\
\text { Engagement }\end{array}$} & \multirow[t]{2}{*}{2} & $\begin{array}{l}\text { "....all of the adults would get so excited when it was the } \\
\text { outdoor portion of the workshop...whatever we were talking } \\
\text { about in class and the demonstrations were all great, and I } \\
\text { enjoyed all of them but as soon as Matthew was like 'time to } \\
\text { go outside' you know, woo, alright! That was what I was } \\
\text { looking forward to was getting out in the park some. And so } \\
\text { it's a good reminder that yes, kids are definitely the same as us } \\
\text { in that regard, they like to get outdoors more." } \\
\text {-Teacher D }\end{array}$ \\
\hline & & $\begin{array}{c}\text { "Throughout the workshops I came to the realization that } \\
\text { getting out of the classroom and giving students a chance to } \\
\text { look at things in a new perspective can really make a } \\
\text { difference. It's great to see how much students like being } \\
\text { outside and the observations they make." } \\
\text {-Teacher C }\end{array}$ \\
\hline
\end{tabular}

The rest of the interview data was organized in two ways: one question was coded

for key phrases and ideas that were expressed during each interview and other questions were used to create richer profiles of each participant in order to express how their PCK was influenced by the workshops. Only question 2, which asked "Now that you have completed X workshops, how would you summarize what you learned?", was coded since 
it was the most appropriate way to sum up the information gained from the answers to that specific question. The coded information from question 2 is shown using a bar graph to clearly show the percentage of teachers who expressed certain phrases or ideas during the interviews. This information is shown in Figure 2.

Figure 2. Coded Interview Answers

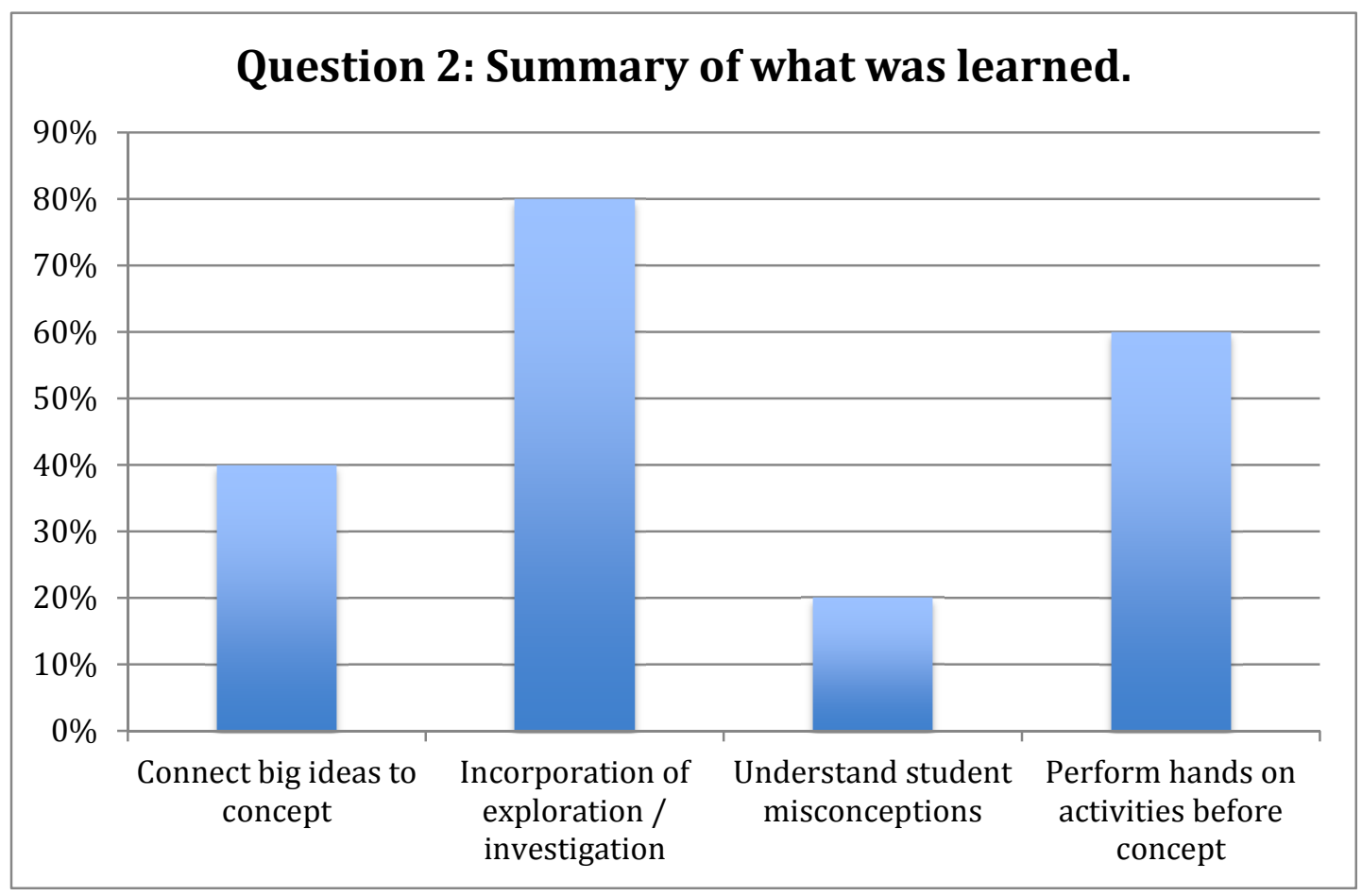

Participant Profiles

Participant $A$. Participant A teaches a combined $5^{\text {th }}$ and $6^{\text {th }}$ grade class at an independent non-profit school for students with learning differences. During the interview, I found out that this kind of professional development geared towards getting teachers to take their students outside wasn't new to Participant A. Many years ago she had been a part of a program called Project Learning Tree, which first inspired her to incorporate more outdoor learning into her curriculum. At the time participant A took place in this 
program, she was teaching at a school that did not have a school garden. So she was encouraged by Project Learning Tree to turn an unused area between two modules to create a massive garden with some of the other teachers. During the interview participant A stated "We created this massive garden and there were all different parts of the garden where you could set up different experiments and different things so no matter what grade you were in there was a part of this, what we called the habitat area, that they could use at their level to do things. So I've always thought that it was crucially important to have hands on information and to be aware of your surroundings."

At this independent non-profit middle school, participant A has done the same thing while attending the Connect2Science workshops and has turned a small area of unused area in the parking lot into a small garden for her class to use. She told me that things that she had always taken for granted when it came to the garden, such as where did some plants come from that were not intentionally planted in the garden or what's going to happen to the orange that someone threw in the garden. Instead of just giving the answers to her students, using the student's fascination with the garden as new opportunities for teaching has really helped her incorporate the observational and investigative practices from the workshops into her classroom.

Besides the fact that participant A enjoyed the subject matter presented in the workshops, she also really appreciated the fact that the workshops gave her an opportunity to get together with other educators once a month. She mentioned in her interview that she was reminded how important it is to get together with other educators and brainstorm ideas.

Another aspect of the workshops that participant A liked were the Page Keeley 
probes. These probes helped remind her how important it is to check for student misconceptions and prior knowledge. She has found that many of her students come into her classroom with holes in their prior knowledge. Participant A found that many of her students lack information that she assumes would have been taught in previous grades.

Due to the holes in student's prior knowledge, Participant A has had to update her lessons in the past in order to fill in gaps in students understanding. She stated "I have to go back and fill in the holes [in prior knowledge] because I have to build on them and I can't build on it without a base".

The one aspect that Participant A took away from the workshops was a reminder to let students observe and investigate things around them, because that's when real learning happens. In the future, Participant A plans to incorporate more chances for her students to observe and investigate, especially using the school garden that the students created.

Participant B. Participant B isn't a science teacher, but he understands the benefits of having a better grasp of science concepts and practices since he supports special education students in all areas. In order to better assist special education students in science, Participant B attended all of the Connect2Science workshop included in this research but also workshops offered in past years. Along with gaining some familiarity with science content and practices, Participant B commented, "I wanted to be inspired for some teaching activities which may or may not relate to what I do, since my focus is math but I think a lot of teaching strategies are related".

For future instruction, Participant B wants to incorporate a couple of the hands on activities that were presented during the workshops. The ones that he brought up all had a math component to them, which fits better with his curriculum. Participant B enjoyed the 
fact that the activities presented in the workshops could easily be done inside, but taking them outside is just as easy and presents a fun new learning environment for students. Students in participant B's class will get outside to measure their shadows and create angles that can be used to teach them geometry in a fun new way.

Participant B understands that it's easy for misconceptions to be created and not addressed properly, especially when it comes to anthropomorphizing other living things. This was in reference to the apple tree probe that was used in the PCK reflection pieces. Participant B commented that it's easy to see how students might think plants get food similar to us since they know the tree needs nourishment to survive and all they know is how creatures like us get food.

Participant C. Next year Participant C is switching grade levels from teaching $5^{\text {th }}$ grade to teaching kindergarten, since there is a high need for dual language teachers in the beginning grades. With this switch, Participant $\mathrm{C}$ is looking forward to starting with a new set of kids who he can take on walks around their schoolyard. Participant $\mathrm{C}$ was inspired by the workshops to get his students outside more and give them a chance to look at things in a new perspective. After the second workshop, Participant $\mathrm{C}$ shared with me that he had started incorporating walks with his $5^{\text {th }}$ graders because he was inspired by the workshops. Unfortunately, he never had great success with having his $5^{\text {th }}$ graders making scientific observations during these walks due to disciplinary issues. He had trouble finding the right way to motivate his students to observe while outside instead of just goofing off half way through the school year. With the switch to a new grade level and new set of students, he is looking forward to incorporating the school garden into his science curriculum and setting up more observational studies for his students using the school garden throughout 
the year.

In the spring Participant $\mathrm{C}$ was even inspired by the workshops to apply for a grant to implement a dual language curriculum that integrated targeted Next Generation Science Standards, which incorporated a local wetland near the school. The workshops influenced participant $\mathrm{C}$ to take a closer look at the surrounding natural areas around his school and how those areas could be incorporated into the science curriculum of the school.

Participant $\mathrm{C}$ enjoyed that the Page Keeley probes gave him a better appreciation for the multiple ideas that students might have about different topics. Doing the probes opened his eyes to how students may have differing misconceptions based on their prior knowledge or even lack of prior knowledge.

Participant D. Participant D taught the $3^{\text {rd }}$ grade before taking a leave of absence to be at home with her two sons. She does not know where and what grade level she will teaching when she returns to teaching, but she definitely wants to incorporate more outdoor learning into her curriculum. In the past, she didn't incorporate outdoor learning experiences into her science curriculum. She commented "I remember I would take them out for some walks out on the playground to notice the changes in the seasons or if we were going to do an art lesson with leaves, then we would go out on the playground and collect leaves for our art project. A lot of the science I did was in the classroom”. Incorporating the schoolyard more into her science curriculum seems very doable, but she wants to maintain going on one big field trip during the school year to a forested natural area. Taking walks with students sets up time to allow students to just make observations about what is around them and then incorporate that into what they are learning at the time. Participant D would also like to try to do more activities outside, even if the activity 
is one that she would normally do inside. She stated "I really can always look for more ideas just to be able to step out of the classroom onto the playground, and I feel like that was [a] really helpful [part of the workshops]".

The probes were inspiring for Participant $\mathrm{D}$, where she can see herself using a modified version to have a class discussion or as a chance for students to share what they think with a partner. Throughout the workshops, Participant D realized that students could have a lot of misconceptions, as well as adults. For her, she didn't find she held any misconceptions about the topics, but she gained a lot of new information that she found interesting.

Participant E. Participant E was in her first year of teaching while she was attending the Connect2Science workshops. She teaches kindergarten, which was only half days this past school year but will be a full school day for the school year. Since she only had her students for half the day, time restraints were one of participant E's biggest challenges in getting students outdoors. She mentioned in the interview "One thing that was a roadblock that was really unexpected to me was the scheduling of the school. Just the logistics of where you are going to go, what the schedule is, because I'm only half day I really only have two hours with the kids."

The science curriculum at Participant E's school is integrated with an inclusive language program. She has found that it's not always science teachers developing the dual-language curriculum, which she noticed might be leading to teaching some misconceptions to the students. Participant E plans on either taking her students outdoors for an experience or bring items in from outside to help students make better connections and help to avoid the spread of further misconceptions. 
"[I want to bring] what they call realia into the classroom, the real trees, the real branches, because the curriculum that they have right now is focused on the language. It's just diagrams, and drawn pictures and labeling, graphic organizers, which is all great stuff and good for kids, but to not see a cone and not feel the dirt in your hands, I mean that's really what I'm going to bring into my classroom. It's so important because I just don't think learning about the outdoors without the outdoors is appropriate.

In the future Participant E plans on taking her students out more, since she will be moving to a full day schedule and will have more time with her students. Participant $\mathrm{E}$ is also going to try to set up at least one scientific investigation with her students in the coming school year. She likes the idea of not just giving students the answers, but letting them figure it out for themselves.

"This idea that you guys always talk about, investigation. I know that is how we want kids to be thinking about science. Well how could you figure that out rather than just answer them. I mean it's a lofty goal but setting up at least one investigation during the year where they have to figure out the answer. That's hard to do as a teacher to take the time to design something like that, but honestly if you let the kids direct it, it probably would just take care of itself because they ask the questions, they have a thirst for knowledge naturally, so I think that's what I'm going to incorporate." 


\section{Chapter 5: Discussion}

The research question for this case study was: In what ways does the Tryon Creek Connect2Science professional development workshop series influence teachers': a) selfefficacy in teaching science outdoors and b) science pedagogical content knowledge? In the following paragraphs I will be breaking down the different aspects of the workshops that influenced participants' self-efficacy, as well as discussing each of the four selfefficacy constructs (instructional practices, student engagement, culturally relevant pedagogy, and classroom management) in detail. After that I will discuss how the workshops influenced participants' science teaching PCK by having the participants experience activities that focused on specific science practices outlined in NGSS. The two science practices that were emphasized during the workshops were Practice 1 observation and asking question and Practice 3 planning and carrying out investigations. Participants were not given any specific content knowledge before engaging in the activities that demonstrated these practices, since the focus was experiencing the science practices from the lens of a student.

\section{Self-Efficacy Constructs}

The results from the self-efficacy survey showed that three of the constructs had significant increases: instructional practice, student engagement, and culturally relevant pedagogy. The fourth construct, classroom management, did not show a significant change. Discussing each construct separately allows me to show the effect that the workshops had on each construct.

Instructional Practices. The results showed that participants' gained the most in the instructional practice construct of the self-efficacy survey, which had the highest p- 
value (0.0184). This is not surprising since participants were actively practicing new instructional practices while learning new activities in each workshop. The main instructional practices that the workshops focused on were allowing the teachers to experience the activities before diving into the concept fully (Activity Before Concept), as well as allowing them to make predictions based on prior knowledge, then make observations and collect data to provide a scientific explanation of everyday phenomenon (Predict-Observe-Explain sequences) (Konicek-Moran \& Keeley, 2015).

These instructional practices relied heavily on some of the science practices outlines in NGSS, such as asking and posing questions, making observations to gather evidence to answer questions, and investigating ecological phenomena to better learn the science content. While on a hike with participants during the first workshop, Connect2Science through Animals, the other instructor and I took a moment along the trail to have participants observe an area where there were multiple worm mounds made out of leaves. Participants were asked to observe a specific area to look for signs of animals. I observed how confused all of the participants looked since they could not figure out what they were supposed to be seeing, which was great since it forced them to ask lots of questions in order to figure it out. Participant A commented on this moment during her interview, "When we went out and did the worm searching, that was interesting because we are all looking at the same spot on the ground, wondering what the instructors might be talking about when they said there is something important here."

Actually performing the hands-on activities before learning about each biological concept certainly influenced participants' self-efficacy in terms of instructional practices. This was also demonstrated in a study done by Moseley, Huss, and Utley (2010), which 
also focused on an outdoor PD program that involved participants actively performing hands-on activities resulted in increased teacher self-efficacy. A couple of the quotes from different participants below help to demonstrate how beneficial it was to run through the activities.

"You don't often go to a class where you are actually doing some of the fun lessons. You go to class and talk about theory, you go to a class and then they talk about ' here is a bunch of handouts on how you can do this' but to actually participate in them as if we were a class was really important and really fun. I really liked that a lot and having that chance during that lesson to make the mistakes that kids are going to make and then talk about what would you do with that." Participant A

"I like doing the activities, not just reading about them or getting a book or packet about them. I am much more likely to take them right to my classroom if I've run through it, even if it's just briefly." Participant D

Participants were developing their self-efficacy in terms of instructional practices through mastery experiences. According to Bandura's social cognitive theory, mastery experiences are the most direct and most powerful sources of information in the development of self-efficacy (Bandura, 1977). Self-efficacy is increased when individuals master or achieve success at a certain task (Bandura, 1997).

While the experience of mastering the activities in the role of students influenced participants' self-efficacy regarding instructional practices, participants' perceived selfefficacy was also influenced by the workshops. Perceived self-efficacy is the belief that one has about their abilities in different situations with whatever skills one possesses (Bandura, 1997). Throughout the workshops participants were put into different situations that demonstrated the use of the science practices of observation and investigation. Together with other participants, they were able to apply the skills they possessed while collaboratively learning about these science practices with other educators. When asked if 
the workshop affected participant's confidence in any way during the interviews, participant E commented that "Yeah, it made me realize how much I actually do know and to be secure in my own background knowledge of science. That I can teach the kids this stuff and I can help them access at their level". Overcoming any self-doubts and achieving a higher personal self-efficacy in science knowledge has been linked to teacher's spending more time teaching science and spending more time developing science concepts using novel and challenging methods in the classroom (Lakshmanan et al., 2011).

Another aspect of the workshop that influenced participants' self-efficacy in instructional practices was the ability to get together with other educators to talk and listen about different ideas. Collaboration was brought up multiple times in three interviews, and while there was never any formal time for participants to collaborate together, I observed multiple conversations during activities and lunch breaks during the workshops where teachers were comparing ideas and collaboratively learning. Participant A said, "I think what the workshops helped to remind me of, maybe didn't learn, was how important it is to try to get with other educators and brainstorm ideas". PD programs that offer teachers opportunities to interact and participate in collaborative relationships with other educators may positively influence self-efficacy (Lakshmanan et al., 2011).

Student Engagement. Participants' self-efficacy in terms of the student engagement construct also showed to be significantly influenced by the PD workshops. The student engagement construct of the self-efficacy had a p-value of 0.0379. Participants' vicarious experiences may be the influence of this significant change in the student engagement construct. Vicarious experiences are a more indirect source of information, where individuals observe someone else modeling a skill or behavior (Bandura, 1977). The 
instructors of the workshops provided vicarious experiences for teachers by modeling the use of outdoor environments for instruction. However, the vicarious experiences of witnessing how other participants reacted to the hands-on activities presented in the outdoor instruction portion of the workshops may have also influenced participants' confidence in engaging students. It has been noted in other research that when pupils are taught in places that explain science in new ways, students often seem to be more enthused (Braund \& Reiss, 2006). Participant D commented “....all of the adults would get so excited when it was the outdoor portion of the workshop... And so it's a good reminder that yes, kids are definitely the same as us in that regard, they like to get outdoors more." This quote helps to demonstrate how participants may have been influenced by witnessing the effect of incorporating outdoor lessons on engagement on other participants.

Culturally Relevant Pedagogy. The third construct identified in the self-efficacy survey was culturally relevant pedagogy. While the results indicate that there was a significant change in this construct, the p-value was very high (0.047), indicating that the workshops did not heavily influence this construct as much as the first two constructs. Culturally relevant pedagogy was not an explicit focus of the workshops, but taking a look back at the survey questions that focused on the construct, a couple of questions were indirectly addressed throughout the workshops. Questions 30 and 31 in the self-efficacy survey dealt with the confidence to make instruction relevant to student's everyday lives and using student interests when teaching science outdoors. Throughout the workshops, outdoor instruction was always tied back to how teachers could use activities presented in the workshops in areas that students were familiar with, such as their schoolyard or in 
natural areas near their schools in order to make lessons more relevant for students. By providing practical out-of-school science lessons in familiar areas, students can find relevance to their lives within these informal outdoor lessons (Braund \& Reiss, 2006).

Classroom Management. It came as no surprise that the classroom management construct had the largest p-value (0.2654), since the PD workshops did not focus on any aspects of classroom management. During the interviews however, participants did mention that classroom management was sometimes a challenge to getting students outside, but was not the main challenge that participants said they dealt with when incorporating outdoor learning experiences. The main challenge that participants said stood in their way of taking students outside for science lessons was the weather.

\section{Pedagogical Content Knowledge}

One of the main aspects of PCK focused on for this research study was participants' understanding of effective strategies when teaching science outdoors, which included strategies to engage students in inquiry and guide any student discourse about life science topics. Teachers should know effective strategies that will help reorganize the understanding of learners, because students are unlikely to come in as blank slates (Shulman, 1986). The effective strategies focused on during the workshops were demonstrating the use of certain instructional practices (Activity Before Concept and Predict-Observe-Explain Sequences) as well as incorporating more of the science practices outlined in the NGSS. The specific science practices that best complimented the two instructional practices focused on throughout the workshops were asking questions based on observations and planning and carrying out investigations using observations and/or 
measurements for collecting data. While observation is not a specific practice in the NGSS, Appendix H of NGSS (NGSS Lead States, 2013) focuses on the nature of science and talks about how observations are an important aspect of how scientists recognize patterns and collect evidence.

The importance of equipping teachers with various effective instructional strategies is to add to their tool belts a multitude of ways that they can better represent content material to students through the use of outdoor lessons. PCK goes beyond content knowledge to the knowledge of teaching, where teachers should know the ways of representing the content in a way that makes it comprehensible for students (Shulman, 1986). After participating in the workshops, participants had a better understanding of how they could use the outdoors to help students reach deeper understandings in a variety of life science topics.

When asked what participants took away from all of the workshops, almost all of the participants mentioned learning more about the Next Generation Science Standards (NGSS). Throughout the interviews, participants would not mention any one specific performance expectation from NGSS, but every participant mentioned some of the NGSS science practices that were emphasized throughout the workshops. Every participant brought up that they were going to encourage students to ask more questions, as well as incorporate more exploration and investigation into their classrooms at some point in the interview process.

Experiencing learning about life science topics through the use of the science practices really helped participants understand how the science practices could be used to enhance student learning. Participant A even commented "My big take away was 
remembering how important it is to simply let kids look at something for a while and observe it. Just using that time to focus on how do you observe something and ask questions to get answers. I think allowing them to do that in class would be huge." Participant E stated "[I want to try to incorporate] this idea that you guys always talked about, investigation, how we want kids to be thinking about science, well how could you figure that out rather than just answer them, but setting up at least one investigation in the year where they figure out the answer is something I want to try to do."

Another main aspect of PCK that was focused on for this research study was participants' knowledge of student prior knowledge and misconceptions. Understanding any possible misconceptions that may arise for students is important when teaching specific science concepts, so to address the idea of misconceptions every workshop included a couple of Page Keeley probes that participants were given. Once participants had time to choose the answer they thought was most correct, there was a group discussion around the implications for teaching the specific topics addressed in the probes.

The PCK reflection piece used in the final workshop to assess participants understanding of student misconceptions was based on a Page Keeley probe (Keeley, 2011) that was designed to help teachers uncover student misconceptions about photosynthesis and where plants get food. By giving the participants the probe first and having them reflect on the correct answer, I was hoping to see if any of the participants actually held a misconception on the topic. The participant responses showed that none of the participants held a misconception about the topic of where trees make food, since all of the participants chose the correct response. This is most likely due to the fact that many of the participants were familiar with the topic. Many teachers express more 
misconceptions when they are unfamiliar with topics and have very little knowledge of potential student problems (Van Driel, Verloop, \& de Vos, 1998). It is important for teachers to be aware of misconceptions that they might hold before they pass them along to their students, but it is equally important for teachers to understand the potential for possible student misconceptions.

While every participant was able to identify at least one misconception and almost all participants were able to describe how those could be addressed, each participant could still have shown a better understanding of possible student misconceptions and how to address them. Having each participant reflect further into what the possible student misconceptions were surrounding the topic and how they would address those specific misconceptions, I hoped to learn a little more about their individual understanding of how to handle student misconceptions. The participants' reflections revealed that there is still some information about how to identify and handle misconceptions that could be learned.

When a teacher is aware of students' misconceptions and lack of understanding, they are better able to make decisions about the best instructional steps to take in order to meet student needs (Cochran, 1991). Even though none of the participants identified all possible student misconceptions, participants were able to adapt their teaching knowledge to align with the specific science content in order to address student misconceptions. An example of this can be seen in part of the response from Participant A where she addresses how she would help students better understand that plants do not get food through the roots or other parts of the plant, which addresses the important concept that plants have different structures that serve different purposes. The response from participant A was "Knowing the parts of a plant would be helpful to teach. I would use individual lessons on 
plant parts through the use of models and other hands-on activities to help solidify what each part does." Participant D identified the same misconception as Participant A "Molly's idea about food being made in the roots is a common misconception students have - they often think plants suck food up through their roots." However, Participant D identified a second misconception that students can have, "some students initially struggle with the idea that plants make their own food, like Jared's idea.”. Participant D was the only participant to identify half of the common misconceptions outlined in Table 5. All other participants only identified one common misconception that was defined in Table 5.

PCK has become a way of understanding the complex relationship between teaching and content through the use of specific teaching strategies (McDonald \& Dominguez, 2010). Participants were given opportunities to process information as students, which helped participants better understand how to enhance student learning in science using the outdoors. Providing participants with more than just content knowledge is crucial in helping teachers' make decisions about how to best instruct students and foster deeper understandings (Cochran, 1991).

A number of participants appreciated that they were in the position of a student or learner while going through the activities demonstrated throughout the workshops. Participant B stated, "I think being in a position of being a learner was very helpful. I always need to have that empathy with kids and I need to do it myself because it's going to help me be a better teacher." Other participants expressed similar sentiments, which can be seen in Table 6.

In order to dig deeper, I addressed the topic of misconceptions during the interviews. When asked if there were any common misconceptions that participants held 
prior to attending the workshops, most participants said that they did not have any moments during the workshops where they realized they held any common misconceptions. Two of the participants did acknowledge that they did have at least one moment where they realized that they did hold a common misconception. One participant recognized that during the workshop Connect2Science through the Sun, he realized that he held the misconception that energy cycled just like matter when really it flows through a system. Participant C commented "There was one misconception I had on the day about the sun because we were talking about the conservation of mass and conservation of energy, and how energy is neither created nor destroyed, but it's something about there's a flow of energy or a cycle of energy instead of an appearance or disappearance, something like that. .... Oh yeah it was that energy flows, it does not cycle." I observed another participant come to terms with a held misconception when given a probe on whether a seed is alive or not. I witnessed this participant as he realized that he held a common misconception that seeds are not alive until they sprout, when really they are alive before that moment. It was great to see participants open up about misconceptions they realized they held and understand how easy it is for misconceptions to take root.

As seen in the participant profiles from the results, many participants gained a renewed sense of importance for understanding student prior knowledge and misconceptions through experiencing the probes. Participant A mentioned that lack of prior knowledge is not new to her since she sees students come into her class every year with what she calls "holes" in their prior knowledge.

"I think you had a good idea of bringing misconceptions out. [Students] come in here with holes, the kinds of holes that I would have thought they 
picked up in 2nd, 3rd, or 4th grade. Now I have to go back and fill them because I have to build on them and I can't build on it without a base. The probing activities and well to think about it in advance, can tell you what is missing in kids, you know they have missing holes and that stuff tells you right away what you have to adapt immediately in that lesson. That was great." Participant A

Participant A communicated during the interview, as seen in the quote above, that she understands how detrimental it can be to not address the lack of knowledge that students have before teaching new material. While gaps in prior knowledge are not the same as commonly held misconceptions, if gaps in prior knowledge are not addressed before learning new material, new student misconceptions can be created.

Other participants over the course of the workshops really began to understand how the probes could help them in their classrooms to better identify student prior knowledge and misconceptions. When asked how the workshops influenced their understanding of student misconceptions and prior knowledge, participant $\mathrm{C}$ answered "I like the idea of having kids engage in some kind of probe activity as a pre-test. I appreciate that the probes we were given did not point out any single misconception, but they helped to possibly identify multiple possible misconceptions. Experiencing the probes gave me a better appreciation for the ideas that students may have and not take for granted that it may not be one or the other."

Another participant answered in a similar way, but took it one step further to say that she might use the probes in different ways, not just as a pre-test. For Participant D the Connect2Science through the Sun workshop helped her develop a stronger PCK 
surrounding weather and climate. Participant D commented "Talking about day length, seasons, weather, and climate, kind of all those topics are connected that kids have a lot of misconceptions about how it works, adults do too. Those probes were really good, that is one book that I would invest in. I think I may need to modify, depending on the grade level I was teaching, but even if I didn't have the kids read them and write, even if we just used it as a discussion, you know, talk with a partner or something similar about what you think." Thinking about using the probes in a different way that is more suited to her teaching style shows that participant D was taking the information from the workshops and applying them to her own teaching style.

Participant E, who teaches kindergarten, took another important realization away from the workshops concerning student misconceptions and prior knowledge. Since she teaches kindergarten and is one of the first sources of information for her students on their formal educational journey, the workshops influenced her to really focus on creating a strong foundation for her students. The probes and activities that helped to address some of the common misconceptions in the probes throughout the workshops helped her to understand how important it is to include the right amount of detail into her lessons in order to help clarify confusing topics for students. The most influential moment for her during the workshops was during the Connect2Science through the Sun workshop, where we gave a couple of probes about seasons and then did a couple of activities involving the interactions between the earth and sun that helped show how to address the misconceptions in the probes. Participant E stated "Well, we talked about this on the sun day, I think, about the difference between seasons and climate and that really opened my eyes up because it was right before we did a weather unit and I was like oh that makes 
more sense! So I was able to put a lot more emphasis on the difference between weather and climate and we talked a little more about the sun, the earth, and everything because I really wanted to be able to address the underlying reason for the difference since I know it only gets more complicated the older they get and the more they learn so I wanted them to have a good foundation. We talked a lot about different parts of the country too, like who's been to Southern California, it's usually warm there in the winter time and why is that?".

\section{Limitations}

There were a few limitations of this study. The main limitation was the timing of the Institutional Review Board (IRB) approval. The IRB approval for this study was not finalized until the end of February, which was after four of the five workshops had already taken place. Due to the timing of the IRB approval, I was not able to do a pre and post assessment of the participants PCK. However, I was able to do a retrospective survey to assess self-efficacy but unfortunately the PCK reflection pieces were unable to be put into a retrospective pre and post format. Due to this limitation, I feel as though I did not get a full feel for any growth in PCK the participants may have experienced over the course of the workshops. I can speculate a little from the PCK reflections that were done during the last workshop, but since I have nothing to compare it to, the information that I can get from those reflections is limited.

Also due to the unfortunate timing of the IRB approval, I was also not able to collect any formal observation recordings throughout the workshops. If I had the IRB approval at the start of the very first workshop, I could have collected observational data 
over the course of all five workshops. I could have videotaped some of the discussions that took place after each probe that was given out during the workshops, which could have given me a richer picture of any impact the workshops had on participant's PCK.

The timing of the workshops was also a limitation of this study. The first workshop was in October, which was only a month and a half after I started graduate school. As the workshops happened, I was still learning and figuring out the details of my research study. Even though this research study was able to document a change in the self-efficacy of participants and tell a story of the workshops incorporated PCK, as well as how that affected participants, having more time to figure out all of the details before the workshops started would have been more ideal.

Another limitation would be the small sample size of this study. While I attempted to reach out to participants that attended at least one workshop, but was not at the final workshop, it was easy to get those that were at the final workshop to agree to be a part of the study and start the data collection procedure with them. Ideally I would have preferred to have a few more participants that had only attended one or two workshops, in order to diversify the treatments that participants received, since four of the five participants in this study attended all five workshops. Having more variety in the number of workshops that participants attended would have helped to pinpoint the areas of the workshops that really influenced participants' self-efficacy and PCK.

\section{Conclusion}

This research suggests that providing educators with new, unique professional development opportunities that provide collaborative hands on learning experiences can 
increase teacher self-efficacy and science pedagogical content knowledge when incorporating more outdoor based, non-traditional learning experiences into their curriculum.

These results support Braund and Reiss's (2006) arguement that incorporating outdoor lessons can be a great tool to help improve the learning of science for many students. Providing PD programs that allow teachers to gain the self efficacy and pedagogical strategies needed to teach science lessons in an outdoor setting can help enhance elementary level science curriculums (Holden et al., 2011; Jung \& Tonso, 2006; McDonald \& Dominguez, 2010; Pecore, Kirchgessner, \& Carruth, 2013; Sandholtz, \& Ringstaff, 2014).

Over the course of five PD workshops, participants' self-efficacy was positively influenced regarding instructional practices and student engagement. We saw the most significant change in self-efficacy in terms of instructional practices, which makes sense since instructional practices that incorporated NGSS science practices into instruction were modeled over the course of five workshops. Not only were instructional practices with science practices modeled, but also participants went through workshops in the position of learners, gaining mastery experiences with the practices (Bandura, 1997).

The two main instructional practices focused on throughout the workshops were Activity Before Concept and Predict-Observe-Explain Sequences (Konicek-Moran \& Keeley, 2015). These instructional practices complimented two of the science practices outlined in NGSS as well: Practice 1(asking questions based on observations) and Practice 3 (planning and conducting investigations). All activities done throughout the workshops emphasized these instructional and science practices and demonstrated how to incorporate 
them into outdoor science lessons. Multiple participants mentioned that they were going to include more opportunities for students to observe before given all of the details of the topic being taught and helping to facilitate more student investigations in their instruction.

As well as learning new instructional strategies that influenced the participants' self-efficacy, participants' science PCK was also impacted. Learning new instructional strategies provided participants with new tools to better help represent science content to students using an outdoor setting. Participants' knowledge of teaching science in an outdoor setting was influenced, where participants learned new ways of using the outdoor surroundings to represent science content in a way that makes it clearer for students (Shulman, 1986). Participants' thoughts on student misconceptions and prior knowledge (add Keely reference) were influenced over the course of the workshops as well. While common misconceptions and prior knowledge were not new concepts to any of the participants, many of them left the workshops with a renewed awareness of student prior knowledge and misconceptions linked to the particular science concepts presented with the workshops. Many participants brought up that they were reminded of how important it is to assess student prior knowledge and uncover any student misconceptions, as well as addressing common misconceptions with effective instructional practices.

\section{Recommendations}

The largest motivating factor for teachers to attend the Connect2Science workshops was the location. All participants mentioned that having the workshops at Tryon Creek State Park was very appealing to them. This reinforces research done by Pecore, Kirchgessner, and Carruth (2013), which showed the positive outcomes of 
providing a PD program in an enjoyable and interactive learning environment that provides authentic learning experiences. One participant stated that "[Tryon Creek] really was an attractive piece for me. Because you have a living lab right there to use.” My recommendation for future PD programs is to have them occur in locations that are enjoyable and help provide authentic learning experiences for participants.

Since the professional development focused on during this research project did not emphasize any management strategies for teaching outdoors, that could be an interesting area for future research studies. Even though it was not a sub-category that was included in the results, the self-efficacy survey that was used for this study has a sub-category that focuses on classroom management. Before starting a PD program focused on outdoor education, it might be beneficial to give participants the self-efficacy survey to see how they view their ability to manage students when teaching outdoors. For this study, most participants rated themselves pretty high on all questions within the classroom management sub-category. This is definitely not the case for all elementary school teachers, where many may avoid outdoor instruction due to management issues.

Managing a classroom of students during an outdoor lesson may be a barrier for many elementary school teachers, and this was identified as an issue for a couple of participants during the interviews for this study. One participant who taught $4^{\text {th }}$ grade during the workshops shared during our interview that they would be teaching a new grade the following year. While this was a big change for participant $C$, they were excited for the opportunity to start fresh with a younger grade since participant $\mathrm{C}$ disclosed that it was hard for him to implement outdoor instruction with the $4^{\text {th }}$ graders due to behavior management. Management strategies that work inside the classroom may not work in an 
outdoor setting. Providing teachers with tips and examples of effective strategies to manage their classes when outdoors may make outdoor lessons more accessible to some elementary teachers. Incorporating ways that teachers can help manage outdoor instruction better into PD programs focused on outdoor education may be very helpful to many elementary teachers.

Along the same lines as classroom management, helping elementary school teachers manage their outdoor instruction time would be helpful. This may mean that developing a PD workshop that focuses on not only helping teachers teach science through outdoor instruction, but instead incorporates other subjects such as language arts and math into outdoor instruction. Incorporating the Common Core Standards along with the Next Generation Science Standards into a PD program may be an effective way to show how language arts and math can be incorporated into outdoor lessons along with science. PD programs should also stress how transitioning a few lessons that encompass multiple subjects to an outdoor setting can help bring context and relevancy into a lesson. During the interviews Participant D stated, "there honestly wasn't always a lot of time to do science in general, unfortunately, it was something that I kind of had to squeeze in around the other core subjects like math, writing, and reading. So if I am already trying to squeeze in a science lesson and time is a constraint as well, taking students outside just takes longer. Everyone has to get all geared up, we have to get out and do our activity and then come back in, where as if we could do the same activity in the classroom then we would maybe save 15 minutes". Developing a PD workshop that provides outdoor learning experiences to teachers that not only include science, but math, writing, and reading, may influence more elementary teachers to teach outside of their classrooms. 
For future research, it would be interesting to see what other aspects of PCK could be focused on, such as participants understanding of learning progressions and creating developmentally appropriate representations for students. Instead of assessing PCK using a reflection piece as I did, having participants create a lesson plan or activity that could be scored using the STEM PCK rubric created by the Portland Metro STEM Partnership based on research Park et al. (2011), Lee et al (2007), and Schneider and Plasman (2011). Also extending the research study beyond just the professional development workshops would be something to consider for future research. Doing follow-up observations with participants to see how they are integrating the outdoors into their science lessons after going through the PD experience may yield more information about how to better influence and support the blending of formal and informal curriculum. 


\section{References}

American Association for the Advancement of Science (AAAS). 2015. Project 2061. Science Assessment beta: Frequency of selecting a misconception.

Appleton, K. (2008). Developing science pedagogical content knowledge through mentoring elementary teachers. Journal of Science Teacher Education, 19(6), 523545 .

Ashton, P. T., \& Webb, R. B. (1986). Making a difference: Teachers' sense of efficacy and student achievement (pp. 125-144). New York: Longman

Bandura, A. (1997). Self-efficacy: The exercise of control (pp. 36- 38, 240 - 243). New York: W.H. Freeman.

Bloom, M. A., Holden, M., Sawey, A. T., \& Weinburgh, M. H. (2010). Promoting the use of outdoor learning spaces by K-12 inservice science teachers through an outdoor professional development experience. In The inclusion of environmental education in science teacher education (pp. 97-110). Springer Netherlands.

Bolshakova, V. L., Johnson, C. C., \& Czerniak, C. M. (2011). "It depends on what science teacher you got": urban science self-efficacy from teacher and student voices. Cultural Studies of Science Education, 6(4), 961-997.

Braund, M., \& Reiss, M. (2006). Towards a more authentic science curriculum: The contribution of out of school learning. International Journal of Science Education, 28(12), 1373-1388.

Cochran, K. F. (1991). Pedagogical Content Knowledge: A Tentative Model for Teacher Preparation.

Feille, K. (2013). Getting outside: Three teachers' stories of using the schoolyard as an integrated tool for elementary teaching. Electronic Journal of Science Education, 17(3).

Holden, M., Groulx, J., Bloom, M. A., \& Weinburgh, M. H. (2011). Assessing Teacher Self-Efficacy through an Outdoor Professional Development Experience. Electronic Journal Of Science Education, 15(2), 1-25.

Jung, M. L., \& Tonso, K. L. (2006). Elementary preservice teachers learning to teach science in science museums and nature centers: A novel program's impact on science knowledge, science pedagogy, and confidence teaching.Journal of Elementary Science Education, 18(1), 15-31.

Keeley, P. (2011). Uncovering Student Ideas in Life Science (Vol. 1). NSTA Press. 
Konicek-Moran, R., \& Keeley, P. (2015). Teaching for Conceptual Understanding in Science. NSTA Press.

Lakshmanan, A., Heath, B. P., Perlmutter, A., \& Elder, M. (2011). The impact of science content and professional learning communities on science teaching efficacy and standards-based instruction. Journal Of Research In Science Teaching, 48(5), 534551 .

Lieberman, G. A., \& Hoody, L. L. (1998). Closing the achievement gap. State Education and Environment Roundtable Report.

McDonald, J. T., \& Dominguez, L. A. (2010). Professional preparation for science teachers in environmental education. In The inclusion of environmental education in science teacher education (pp. 17-30). Springer Netherlands.

Moseley, C., Huss, J., \& Utley, J. (2010). Assessing K-12 Teachers' Personal Environmental Education Teaching Efficacy and Outcome Expectancy. Applied Environmental Education \& Communication, 9(1), 5-17.

National Science Foundation. (2012). Advancing informal STEM learning (AISL). Retrieved from http://www.nsf.gov/pubs/2012/nsf12560/nsf12560.htm.

National Research Council (NRC). (1996). National science education standards. Washington, DC: National Academy Press.

NGSS Lead States. (2013). Next Generation Science Standards: For states, by states. Washington, DC: The National Academies Press.

Pecore, J. L., Kirchgessner, M. L., \& Carruth, L. L. (2013). Changes in Science Content Knowledge and Attitudes toward Science Teaching of Educators Attending a Zoobased Neuroscience Professional Development. The Clearing House: A Journal of Educational Strategies, Issues and Ideas, 86(6), 238-245.

Sandholtz, J., \& Ringstaff, C. (2013). Assessing the impact of teacher professional development on science instruction in the early elementary grades in rural US schools. Professional Development In Education, 39(5), 678-697.

Sandholtz, J., \& Ringstaff, C. (2014). Inspiring instructional change in elementary school science: The relationship between enhanced self-efficacy and teacher practices. Journal Of Science Teacher Education, 25(6), 729-751.

Saxton, E., Burns, R., Holveck, S., Kelley, S., Prince, D., Rigelman, N., \& Skinner, E. A. (2014). A Common Measurement System for K-12 STEM education: Adopting an educational evaluation methodology that elevates theoretical foundations and systems thinking. Studies in Educational Evaluation,40, 18-35. 
Shulman, L. S. (1986). Those who understand: Knowledge growth in teaching. Educational researcher, 4-14.

Tschannen-Moran, M., Hoy, A. W., \& Hoy, W. K. (1998). Teacher efficacy: Its meaning and measure. Review of educational research, 68(2), 202-248.

Van Driel, J. H., Verloop, N., \& de Vos, W. (1998). Developing science teachers' pedagogical content knowledge. Journal of research in Science Teaching, 35(6), 673-695. 


\section{Appendix A. Survey Instrument}

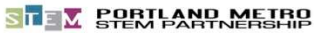

\section{Teacher Self-Efficacy Survey}

This is a retrospective pre/post survey. Please answer each question twice. Circle the number in each column that best represents where you were BEFORE the workshop and where you are AFTER the workshop.

Survey Scale:
\begin{tabular}{|c|c|c|c|c|c|c|c|c|}
\hline $\begin{array}{c}\text { None at } \\
\text { all }\end{array}$ & 2 & $\begin{array}{c}\text { Very } \\
\text { Little }\end{array}$ & & $\begin{array}{c}\text { Some } \\
\text { Degree }\end{array}$ & & $\begin{array}{c}\text { Quite a } \\
\text { bit }\end{array}$ & & $\begin{array}{c}\text { A great } \\
\text { deal }\end{array}$ \\
\hline 1 & 2 & 3 & 4 & 5 & 6 & 7 & 8 & 9 \\
\hline
\end{tabular}

\begin{tabular}{|c|c|c|}
\hline BEFORE the workshop & & AFTER the workshop \\
\hline $\begin{array}{lllllllll}1 & 2 & 3 & 4 & 5 & 6 & 7 & 8 & 9\end{array}$ & $\begin{array}{l}\text { 1. How much could/can you do to get through to the most challenging } \\
\text { students when teaching science experiences in an outdoor setting? }\end{array}$ & $\begin{array}{lllllllll}1 & 2 & 3 & 4 & 5 & 6 & 7 & 8 & 9\end{array}$ \\
\hline $\begin{array}{lllllllll}1 & 2 & 3 & 4 & 5 & 6 & 7 & 8 & 9\end{array}$ & $\begin{array}{l}\text { 2. How much could/can you do to help your students think critically about } \\
\text { science in an outdoor setting? }\end{array}$ & $\begin{array}{lllllllll}1 & 2 & 3 & 4 & 5 & 6 & 7 & 8 & 9\end{array}$ \\
\hline $\begin{array}{lllllllll}1 & 2 & 3 & 4 & 5 & 6 & 7 & 8 & 9\end{array}$ & $\begin{array}{l}\text { 3. How much could/can you do to control disruptive behavior when } \\
\text { teaching science experiences in an outdoor setting? }\end{array}$ & $\begin{array}{lllllllll}1 & 2 & 3 & 4 & 5 & 6 & 7 & 8 & 9\end{array}$ \\
\hline $\begin{array}{lllllllll}1 & 2 & 3 & 4 & 5 & 6 & 7 & 8 & 9\end{array}$ & $\begin{array}{l}\text { 4. How much could/can you do to motivate students who show low } \\
\text { interest in science related schoolwork in an outdoor setting? }\end{array}$ & $\begin{array}{lllllllll}1 & 2 & 3 & 4 & 5 & 6 & 7 & 8 & 9\end{array}$ \\
\hline $\begin{array}{lllllllll}1 & 2 & 3 & 4 & 5 & 6 & 7 & 8 & 9\end{array}$ & $\begin{array}{l}\text { 5. To what extent could/can you make your expectations clear about } \\
\text { student behavior while teaching science experience in an outdoor setting? }\end{array}$ & $\begin{array}{lllllllll}1 & 2 & 3 & 4 & 5 & 6 & 7 & 8 & 9\end{array}$ \\
\hline $\begin{array}{lllllllll}1 & 2 & 3 & 4 & 5 & 6 & 7 & 8 & 9\end{array}$ & $\begin{array}{l}\text { 6. How much could/can you do to get students to believe they can do well } \\
\text { in science related schoolwork by teaching in an outdoor setting? }\end{array}$ & $\begin{array}{lllllllll}1 & 2 & 3 & 4 & 5 & 6 & 7 & 8 & 9\end{array}$ \\
\hline $\begin{array}{lllllllll}1 & 2 & 3 & 4 & 5 & 6 & 7 & 8 & 9\end{array}$ & $\begin{array}{l}\text { 7. How well could/can you respond to difficult science questions from your } \\
\text { students while teaching in an outdoor setting? }\end{array}$ & $\begin{array}{lllllllll}1 & 2 & 3 & 4 & 5 & 6 & 7 & 8 & 9\end{array}$ \\
\hline $\begin{array}{lllllllll}1 & 2 & 3 & 4 & 5 & 6 & 7 & 8 & 9\end{array}$ & $\begin{array}{l}\text { 8. How well could/can you establish routines to keep activities running } \\
\text { smoothly while teaching science experiences in an outdoor setting? }\end{array}$ & $\begin{array}{lllllllll}1 & 2 & 3 & 4 & 5 & 6 & 7 & 8 & 9\end{array}$ \\
\hline $\begin{array}{lllllllll}1 & 2 & 3 & 4 & 5 & 6 & 7 & 8 & 9\end{array}$ & $\begin{array}{l}\text { 9. How much could/can you do to help your students value learning } \\
\text { science experiences in an outdoor setting? }\end{array}$ & $\begin{array}{lllllllll}1 & 2 & 3 & 4 & 5 & 6 & 7 & 8 & 9\end{array}$ \\
\hline
\end{tabular}

PMSP Office of Research \& Assessment

Jerian.Abel@pdxstem.org 


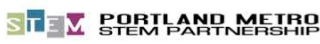

\section{Teacher Self-Efficacy Survey}

\begin{tabular}{|c|c|c|}
\hline BEFORE the workshop & & AFTER the workshop \\
\hline $\begin{array}{lllllllll}1 & 2 & 3 & 4 & 5 & 6 & 7 & 8 & 9\end{array}$ & $\begin{array}{l}\text { 10. How much could/can you gauge student comprehension of what you } \\
\text { have taught in science related activities in an outdoor setting? }\end{array}$ & $\begin{array}{lllllllll}1 & 2 & 3 & 4 & 5 & 6 & 7 & 8 & 9\end{array}$ \\
\hline $\begin{array}{lllllllll}1 & 2 & 3 & 4 & 5 & 6 & 7 & 8 & 9\end{array}$ & $\begin{array}{l}\text { 11. To what extent could/can you craft good scientific questions for your } \\
\text { students that relate to an outdoor setting? }\end{array}$ & $\begin{array}{lllllllll}1 & 2 & 3 & 4 & 5 & 6 & 7 & 8 & 9\end{array}$ \\
\hline $\begin{array}{lllllllll}1 & 2 & 3 & 4 & 5 & 6 & 7 & 8 & 9\end{array}$ & $\begin{array}{l}\text { 12. How much could/can you do to foster student creativity in science } \\
\text { experiences centered on an outdoor setting? }\end{array}$ & $\begin{array}{lllllllll}1 & 2 & 3 & 4 & 5 & 6 & 7 & 8 & 9\end{array}$ \\
\hline $\begin{array}{lllllllll}1 & 2 & 3 & 4 & 5 & 6 & 7 & 8 & 9\end{array}$ & $\begin{array}{l}\text { 13. How much could/can you do to get children to follow rules while in an } \\
\text { teaching outside of the normal classroom setting? }\end{array}$ & $\begin{array}{lllllllll}1 & 2 & 3 & 4 & 5 & 6 & 7 & 8 & 9\end{array}$ \\
\hline $\begin{array}{lllllllll}1 & 2 & 3 & 4 & 5 & 6 & 7 & 8 & 9\end{array}$ & $\begin{array}{l}\text { 14. How much could/can you do to improve the understanding of a student } \\
\text { who is under-performing in science through teaching in an outdoor setting? }\end{array}$ & $\begin{array}{lllllllll}1 & 2 & 3 & 4 & 5 & 6 & 7 & 8 & 9\end{array}$ \\
\hline $\begin{array}{lllllllll}1 & 2 & 3 & 4 & 5 & 6 & 7 & 8 & 9\end{array}$ & $\begin{array}{l}\text { 15. How much could/can you do to calm a student who is disruptive while } \\
\text { teaching in an outdoor setting? }\end{array}$ & $\begin{array}{lllllllll}1 & 2 & 3 & 4 & 5 & 6 & 7 & 8 & 9\end{array}$ \\
\hline $\begin{array}{lllllllll}1 & 2 & 3 & 4 & 5 & 6 & 7 & 8 & 9\end{array}$ & $\begin{array}{l}\text { 16. How well could/can you establish a management system with each } \\
\text { group of students while teaching outside of the normal classroom setting? }\end{array}$ & $\begin{array}{lllllllll}1 & 2 & 3 & 4 & 5 & 6 & 7 & 8 & 9\end{array}$ \\
\hline $\begin{array}{lllllllll}1 & 2 & 3 & 4 & 5 & 6 & 7 & 8 & 9\end{array}$ & $\begin{array}{l}\text { 17. How much could/can you do to adjust your lessons to the proper level } \\
\text { for individual students in science experiences centered on an outdoor } \\
\text { setting? }\end{array}$ & $\begin{array}{lllllllll}1 & 2 & 3 & 4 & 5 & 6 & 7 & 8 & 9\end{array}$ \\
\hline $\begin{array}{lllllllll}1 & 2 & 3 & 4 & 5 & 6 & 7 & 8 & 9\end{array}$ & $\begin{array}{l}\text { 18. How much could/can you use a variety of assessment strategies in } \\
\text { science experiences centered on an outdoor setting? }\end{array}$ & $\begin{array}{lllllllll}1 & 2 & 3 & 4 & 5 & 6 & 7 & 8 & 9\end{array}$ \\
\hline $\begin{array}{lllllllll}1 & 2 & 3 & 4 & 5 & 6 & 7 & 8 & 9\end{array}$ & $\begin{array}{l}\text { 19. How well could/can you refocus students who are off-task to preserve } \\
\text { the goals of your science lesson while teaching in an outdoor setting? }\end{array}$ & $\begin{array}{lllllllll}1 & 2 & 3 & 4 & 5 & 6 & 7 & 8 & 9\end{array}$ \\
\hline $\begin{array}{lllllllll}1 & 2 & 3 & 4 & 5 & 6 & 7 & 8 & 9\end{array}$ & $\begin{array}{l}\text { 20. To what extent could/can you provide an alternative explanation or } \\
\text { outdoor example to students who are confused about science material? }\end{array}$ & $\begin{array}{lllllllll}1 & 2 & 3 & 4 & 5 & 6 & 7 & 8 & 9\end{array}$ \\
\hline $\begin{array}{lllllllll}1 & 2 & 3 & 4 & 5 & 6 & 7 & 8 & 9\end{array}$ & 21. How well could/can you respond to defiant students, in general? & $\begin{array}{lllllllll}1 & 2 & 3 & 4 & 5 & 6 & 7 & 8 & 9\end{array}$ \\
\hline $\begin{array}{lllllllll}1 & 2 & 3 & 4 & 5 & 6 & 7 & 8 & 9\end{array}$ & $\begin{array}{l}\text { 22. How much could/can you assist families in helping their children do well } \\
\text { in science related schoolwork? }\end{array}$ & $\begin{array}{lllllllll}1 & 2 & 3 & 4 & 5 & 6 & 7 & 8 & 9\end{array}$ \\
\hline $\begin{array}{lllllllll}1 & 2 & 3 & 4 & 5 & 6 & 7 & 8 & 9\end{array}$ & $\begin{array}{l}\text { 23. How well could/can you implement alternative strategies when teaching } \\
\text { science lessons in an outdoor setting? }\end{array}$ & $\begin{array}{lllllllll}1 & 2 & 3 & 4 & 5 & 6 & 7 & 8 & 9\end{array}$ \\
\hline
\end{tabular}

PMSP Office of Research \& Assessment

Jerian.Abel@pdxstem.org 


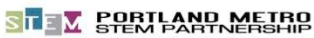

\section{Teacher Self-Efficacy Survey}

\begin{tabular}{|c|c|c|}
\hline BEFORE the workshop & & AFTER the workshop \\
\hline $\begin{array}{lllllllll}1 & 2 & 3 & 4 & 5 & 6 & 7 & 8 & 9\end{array}$ & $\begin{array}{l}\text { 24. How well could/can you provide appropriate challenges for very } \\
\text { capable students in science experiences centered on an outdoor setting? }\end{array}$ & $\begin{array}{lllllllll}1 & 2 & 3 & 4 & 5 & 6 & 7 & 8 & 9\end{array}$ \\
\hline $\begin{array}{lllllllll}1 & 2 & 3 & 4 & 5 & 6 & 7 & 8 & 9\end{array}$ & $\begin{array}{l}\text { 25. How well could/can you develop a community of learners when your } \\
\text { class consists of students from diverse backgrounds when teaching } \\
\text { science in an outdoor setting? }\end{array}$ & $\begin{array}{lllllllll}1 & 2 & 3 & 4 & 5 & 6 & 7 & 8 & 9\end{array}$ \\
\hline $\begin{array}{lllllllll}1 & 2 & 3 & 4 & 5 & 6 & 7 & 8 & 9\end{array}$ & $\begin{array}{l}\text { 26. How well could/can you use your students' cultural background to help } \\
\text { make learning meaningful in science topics that are taught in an outdoor } \\
\text { settlng? }\end{array}$ & $\begin{array}{lllllllll}1 & 2 & 3 & 4 & 5 & 6 & 7 & 8 & 9\end{array}$ \\
\hline $\begin{array}{lllllllll}1 & 2 & 3 & 4 & 5 & 6 & 7 & 8 & 9\end{array}$ & $\begin{array}{l}\text { 27. To what extent could/can you revise materials to include a better } \\
\text { representation of cultural groups in science when taught in an outdoor } \\
\text { setting? }\end{array}$ & $\begin{array}{lllllllll}1 & 2 & 3 & 4 & 5 & 6 & 7 & 8 & 9\end{array}$ \\
\hline $\begin{array}{lllllllll}1 & 2 & 3 & 4 & 5 & 6 & 7 & 8 & 9\end{array}$ & $\begin{array}{l}\text { 28. How well could/can you critically examine the curriculum to determine } \\
\text { whether it reinforces negative cultural stereotypes in science when taught } \\
\text { in an outdoor setting? }\end{array}$ & $\begin{array}{lllllllll}1 & 2 & 3 & 4 & 5 & 6 & 7 & 8 & 9\end{array}$ \\
\hline $\begin{array}{lllllllll}1 & 2 & 3 & 4 & 5 & 6 & 7 & 8 & 9\end{array}$ & $\begin{array}{l}\text { 29. To what extent could/can you use examples that are familiar to } \\
\text { students from diverse cultural backgrounds when teaching science in an } \\
\text { outdoor setting? }\end{array}$ & $\begin{array}{lllllllll}1 & 2 & 3 & 4 & 5 & 6 & 7 & 8 & 9\end{array}$ \\
\hline $\begin{array}{lllllllll}1 & 2 & 3 & 4 & 5 & 6 & 7 & 8 & 9\end{array}$ & $\begin{array}{l}\text { 30. How well could/can you explain new concepts using examples that are } \\
\text { taken from your student's everyday lives when teaching science in an } \\
\text { outdoor setting? }\end{array}$ & $\begin{array}{lllllllll}1 & 2 & 3 & 4 & 5 & 6 & 7 & 8 & 9\end{array}$ \\
\hline $\begin{array}{lllllllll}1 & 2 & 3 & 4 & 5 & 6 & 7 & 8 & 9\end{array}$ & $\begin{array}{l}\text { 31. To what extent could/can you use the interests of your students to } \\
\text { make learning meaningful for them when teaching science in an outdoor } \\
\text { setting? }\end{array}$ & $\begin{array}{lllllllll}1 & 2 & 3 & 4 & 5 & 6 & 7 & 8 & 9\end{array}$ \\
\hline $\begin{array}{lllllllll}1 & 2 & 3 & 4 & 5 & 6 & 7 & 8 & 9\end{array}$ & $\begin{array}{l}\text { 32. To what extent could/can you identify how ways your students' } \\
\text { communicate at home may differ from your classroom/school } \\
\text { communication norms when teaching science in an outdoor setting? }\end{array}$ & $\begin{array}{lllllllll}1 & 2 & 3 & 4 & 5 & 6 & 7 & 8 & 9\end{array}$ \\
\hline $\begin{array}{lllllllll}1 & 2 & 3 & 4 & 5 & 6 & 7 & 8 & 9\end{array}$ & $\begin{array}{l}\text { 33. How well can you implement strategies to minimize the effects of the } \\
\text { mismatch between your student's home culture and your classroom/school } \\
\text { culture when teaching science in an outdoor setting? }\end{array}$ & $\begin{array}{lllllllll}1 & 2 & 3 & 4 & 5 & 6 & 7 & 8 & 9\end{array}$ \\
\hline
\end{tabular}

PMSP Office of Research \& Assessment

Jerian.Abel@pdxstem.org 


\section{Connect2Science}

What was most helpful about this workshop?

How we can improve this workshop?

What additional topics and/or experiences would you like to see in future workshops? 
Appendix B. Overview of Workshops

\begin{tabular}{|c|c|c|}
\hline Work Shop Description & $\begin{array}{c}\text { Total } \\
\text { Attendance }\end{array}$ & $\begin{array}{c}\text { Study } \\
\text { Participants }\end{array}$ \\
\hline $\begin{array}{l}\text { Title: Connect2Science through Animals } \\
\text { Topic description: Throughout the day, participants explored } \\
\text { common misconceptions and activities surrounding why } \\
\text { different animal structures serve different functions, and } \\
\text { different body parts help animals survive in different } \\
\text { environment as well as processes information from their } \\
\text { surrounding environment. Experiences and activities } \\
\text { throughout the day related to the Disciplinary Core Ideas } \\
\text { (DCI's) and essential questions listed below. } \\
\text { DCI's: LS1.A: Structure and Function, LS1.D: Information } \\
\text { Processing, LS4.C: Adaptation } \\
\text { Essentials Questions: } \\
\text { - Where do animals live and why do they live there? } \\
\text { - What are some ways plants and animals meet their } \\
\text { needs so that they can survive and grow? } \\
\text { - How many types of living things live in a place?" } \\
\text { How do internal and external structures support the } \\
\text { survival, growth, behavior, and reproduction of } \\
\text { plants and animals? } \\
\text { How do organisms live, grow, respond to their } \\
\text { environment, and reproduce? }\end{array}$ & 5 & $\begin{array}{l}\text { Teacher A } \\
\text { Teacher B } \\
\text { Teacher C } \\
\text { Teacher D }\end{array}$ \\
\hline $\begin{array}{l}\text { Title: Connect2Science through the Sun } \\
\text { Topic description: Throughout the day, participants explored } \\
\text { common misconceptions and activities surrounding climate } \\
\text { and weather and the transfer of matter and energy though } \\
\text { ecosystems. Experiences and activities throughout the day } \\
\text { related to the DCI's and essential questions listed below. } \\
\text { DCI's: PS3.B: Conservation of energy and energy transfer, } \\
\text { ESSI.B: Earth and the Solar System, LS1.C: Organization for } \\
\text { Matter and Energy Flow in Organisms, PS3.D: Energy in } \\
\text { Chemical Processes and Everyday Life } \\
\text { Essential Questions: } \\
\text { - What is energy? } \\
\text { - What are predictable patterns caused by Earth's } \\
\text { movement in the solar system? } \\
\text { - How do lengths and directions of shadows or relative } \\
\text { lengths of day and night change from day to day } \\
\text { How is energy transferred between objects or } \\
\text { systems? } \\
\text { - Where does the energy in food come from and what } \\
\text { is it used for? } \\
\text { - How do matter and energy move through an } \\
\text { ecosystem? } \\
\text { If energy is conserved, why do people say it is } \\
\text { produced or used? }\end{array}$ & 6 & $\begin{array}{l}\text { Teacher A } \\
\text { Teacher B } \\
\text { Teacher C } \\
\text { Teacher D }\end{array}$ \\
\hline $\begin{array}{l}\text { Title: Connect2Science through Water } \\
\text { Topic description: Throughout the day, participants' }\end{array}$ & 8 & $\begin{array}{l}\text { Teacher A } \\
\text { Teacher B }\end{array}$ \\
\hline
\end{tabular}




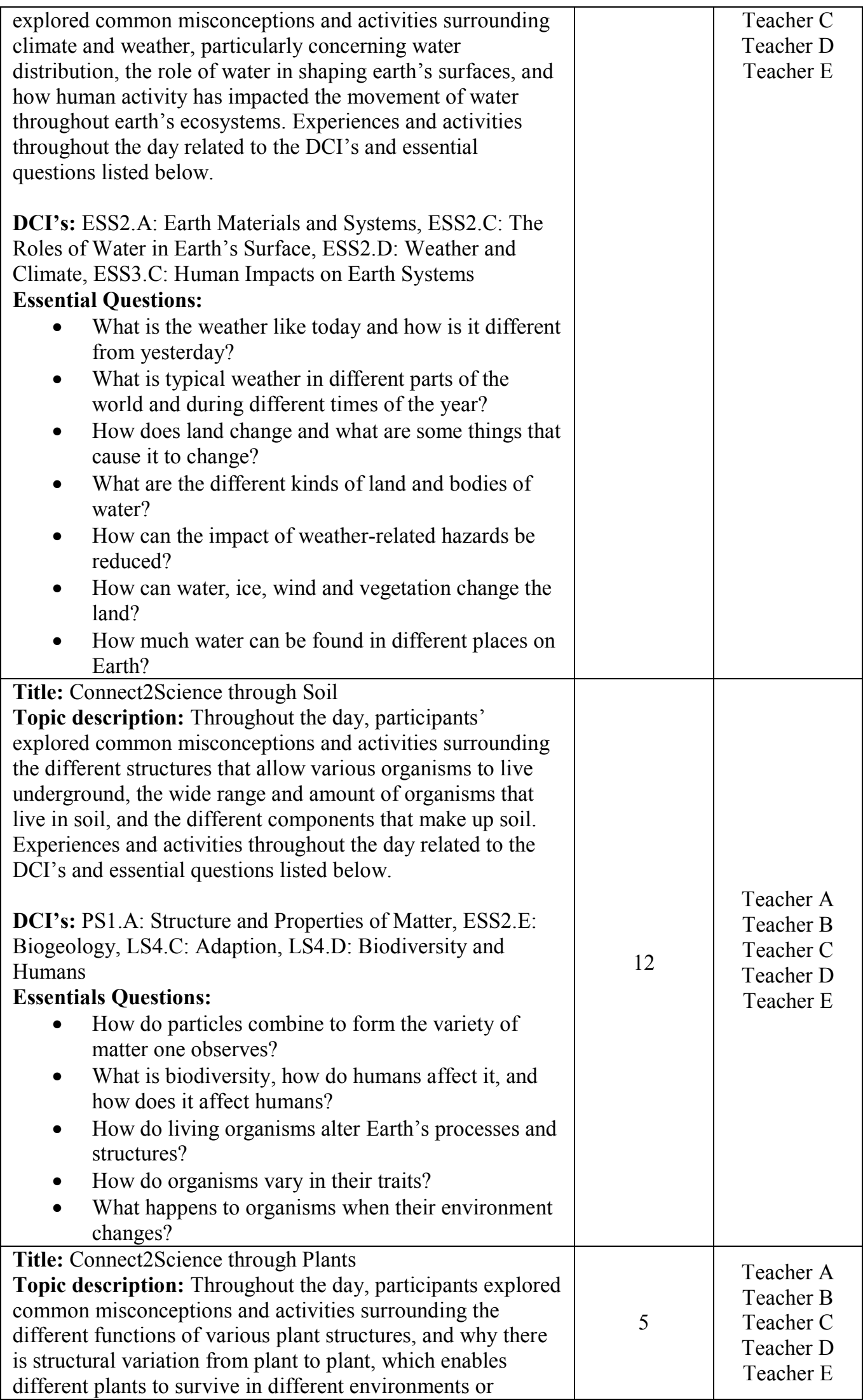


successfully compete with other plants in the same

environment. Experiences and activities throughout the day

related to the Disciplinary Core Ideas (DCI's) and essential

questions listed below.

DCI's: LS1.A: Structure and Function, LS1.B: Growth and Development of organism, LS1.D: Information Processing, LS2.A: Interdependent Relationships in Ecosystems, LS4.C: Adaptation,

Essentials Questions:

- What are some ways plants and animals meet their needs so that they can survive and grow?

- What do plants need to grow?

- How do the structures of organisms enable life's functions?

- How do organisms vary in their traits?

- How do organisms obtain and use the matter and energy they need to live and grow?

- How do organisms grow and develop? 


\title{
Appendix C. IRB Approval Letter
}

\author{
胥 Portland State \\ Post Office Box 751 \\ 503-725-2227 tel \\ Portland, Oregon 97207-0751 503-725-8170 fax \\ Human Subjects Research Review Committec \\ hsrrceplists.pdx.edu \\ Date: February 17,2015 \\ To: Melissa Potter / Ashley Fanning \\ From: Karen Cellarius, HSRRC Chair

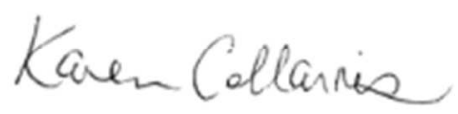 \\ Re: HSRRC approval for your project titled, "In what ways does a nature based professional development program influence \\ teachers: a) self-efficacy in teaching science outdoors, b) science pedagogical content knowledge and c) ability to transfer \\ that knowledge to an outdoor setting?" \\ HSRRC Proposal \# 153303
}

Approval-Expiration: February 17, 2015 - February 16, 2016

Review Type: Expedited, Category 7

In accordance with your request, the PSU Human Subjects Research Review Committee has reviewed your request for approval of the project referenced above for compliance with PSU and DHHS policies and regulations covering the protection of human subjects. The Committee is satisfied that your provisions for protecting the rights and welfare of all subjects participating in the research are adequate, and your project is approved. Please note the following requirements:

Approval: You are approved to conduct this research study only during the period of approval cited above; and the research must be conducted according to the plans and protocol submitted (approved copy enclosed).

Consent: Signed consent is required from all participants in this study.

Changes to Protocol: Any changes in the proposed study, whether to procedures, survey instruments, consent forms or cover letters, must be outlined and submitted to the Committee immediately. The proposed changes cannot be implemented before they have been reviewed and approved by the Committee.

Continuing Review: This approval willexpire on 02/16/2016, It is the investigator's responsibility to ensure that a Continuing Review Report on the status of the project is submitted to the HSRRC two months before the expiration date, and that approval of the study is kept current. The Continuing Review Report is available at www.rsp.pdx.edu/compliance human.php and in the Office of Research and Strategic Partnerships (RSP).

Adverse Reactions and/or Unanticipated Problems: If any adverse reactions or unanticipated problems occur as a result of this study, you are required to notify the Committee immediately. If the issue is serious, approval may be withdrawn pending an investigation by the Committee.

Completion of Study: Please notify the Committee as soon as your research has been completed. Study records, including protocols and signed consent forms for each participant, must be kept by the investigator in a secure location for three years following completion of the study (or per any requirements specified by the project's funding agency).

If you have questions or concerns, please contact the Office of Research Integrity in the PSU RSP at 503-725-2227. 